\title{
Geodetic and Architectural Inventory of the Historic Wooden Church of St. Szczepan in Mnichów (Poland) in Terms of Safety Assessment of the Geometric Condition of the Structure.
}

Tomasz Lipecki ( $\sim$ lipecki@agh.edu.pl )

AGH University

Research article

Keywords: deformation analysis, laser scanning, geodetic inventory, 3D model, 3D reconstruction, geometric condition, structure safety, historic church

Posted Date: November 19th, 2020

DOI: https://doi.org/10.21203/rs.3.rs-107843/v1

License: (c) (1) This work is licensed under a Creative Commons Attribution 4.0 International License. Read Full License 


\section{Abstract}

The article concerns the method of architectural inventory of the historic, wooden church in Mnichów (southern Poland), built in the 18th century. During hundreds of years of operation, structural changes can be seen in it, as well as in objects located above mining operations. The article explains the principles of inventory and describes the applied method of laser scanning, starting from the design to the creation of a 3D solid model of the object, paying particular attention to the analysis based on the created point cloud. Thanks to them, the area and volumes of all rooms were determined, the verticality of columns supporting the church levels was assessed, the floor level and verticality of walls were determined, as well as the shape and level of the roof edges. Based on the research, it can be concluded that the church, as an example of a wooden religious monument, is in good condition. The detected deformations in this range do not have a destructive effect on the current state of the object, but it should be subjected to control measurements in a cyclical manner. The laser scanning method used allowed for a wide and accurate scope of the study of the geometry of the church structure, without the need to disorganize its equipment.

\section{Introduction}

The historical heritage of each nation is also associated with buildings that testify to the cultural development and traditions of the country. One of the examples that confirm this thesis most is religious architecture. In Poland, we have small Romanesque churches, monumental Gothic, sophisticated Baroque, but also wooden churches. They are a living testimony that very often survived several hundred years despite the total devastation of the country in times of many wars. For this reason, it is necessary to take great care of their good condition, which will allow them to be preserved for future generations. One of the activities enabling the assessment of structure stability is the analysis of the geometry of the object and the assessment of its changes in terms of the study of structure deformation. In Poland, it is called geodetic and architectural inventory, performed with the help of geodetic measurements.

The aim of the inventory is to faithfully reproduce the spatial layout, interior design, technical and functional structure of architectural objects. It is a representation of the appearance of an object in a descriptive or pictorial form and contains brick and wooden architecture objects, interior design items and individual details. In Poland, in 1980, the Main Office of Geodesy and Cartography issued Technical Guidelines G3.4 [1], whose entries are still used. According to this instruction, architectural inventory should contain materials and information that present the current state of the object. The results of the inventory are presented in a descriptive and graphic form. They constitute a historical document that can be used for works related to the protection of the facility or its revaluation. According to Mieczysław Kurzątkowski Little Dictionary of Monuments Protection [2], the concept of inventory can be divided into:

1. Measurement inventory - these are drawings made on an appropriate scale on the basis of direct measurement. 
2. Geodetic inventory - a drawing made on a scale based on measurement with a geodetic instrument, showing the building and its surroundings.

3. Photogrammetric inventory - the photos are taken with photographic cameras, then processed with an autograph into drawings at the appropriate scale. This technique accurately reproduces all the details, deformations, irregularities and defects of buildings.

4. Photographic inventory - it is a collection of photos that are taken at the same time.

The above-mentioned types of inventory complement each other giving reliable information about the building.

According to Falkowski, Uchański and Sörensen [3], "the process of developing an inventory of an object can be divided into the following stages:

- determining the nature and structure of the object and the purpose for which the inventory is carried out ;

- measurement - obtaining "raw" data - etc.,

- geometry modeling - recreating the geometry of individual elements of the object,

- supplementing the geometrical part with a descriptive part about the materials used, etc.

- interpretation of the results obtained - creating a descriptive (semantic) model."

Inventory documentation allows to assess the technical condition of the object, planning maintenance and modifications. It also gives the possibility to reconstruct elements of the object in case of their damage or destruction. Conservators of monuments value the most accurate inventory containing architectural details, as it allows you to plan their conservation. In recent years, a new measurement technology [4] has been introduced, which is laser scanning, which allows texture of the point cloud using digital images or the so-called "Intensity image", electronic leveling and orientation of the instrument in the field (giving it global coordinates). Elements of the measured object such as edges and corners are not measured directly. They must be modeled based on the measured point cloud. The result of the inventory carried out with the help of laser scanning may be the point cloud itself if elements of the scanner's external orientation are determined in advance. From the point cloud, you can read measures and generate cross-sections. Currently existing standards in Poland allow only one form of inventory taking, which is creating an inventory drawing. It can be made in the form of a three-dimensional vector model, provided that it contains all the information that is to appear in the two-dimensional drawing. There is a lot of Polish Standards [1] about architectural inventory - 13 standards regarding geodesy and many others describing techniques and methods for preparing technical drawings and dimensioning in construction. However, they are not homogeneous. Arranging and harmonizing standards would help create unified requirements for the description and presentation of architectural inventory, carried out by means of terrestrial laser scanning.

For many years there has been a discussion in world literature on the possibility of using terrestrial laser scanning (TLS) in architectural, archaeological and historical inventories. Examples of the possibilities of 
using TLS measurements are articles describing the experiences of researchers in the inventory of ancient buildings $[5,6,7]$. They indicate that in order to obtain a correct result, an appropriately planned measurement procedure should be performed [8], but it is also necessary to constantly broaden the knowledge about the possibilities of applying new measurement techniques [9]. Thanks to this, it is possible, for example, to reconstruct the gothic vault of the chapel [10], and recreate medieval castles [11, 12] in digital form, even with the use of open-source software [13]. This enables the ancient times [14] to be connected virtually with modern times.

In order to correctly recreate reality, the authors of [15] emphasize that the geometry determined by measurements must be accurate and should provide the level of precision necessary for quantitative diagnostics. For this purpose, research on technology with the use of TLS has been repeatedly presented in terms of the accuracy of the so-called point cloud, which reproduces the measured objects in virtual space. The authors of the publications refer to this: $[16,17,18,19,20]$, who prove that this technology in various forms is an excellent tool for the precise reconstruction of architectural objects and monuments, starting from small elements and ending with building complexes. It should be noted critical voices [21], which pay attention to supplementing such measurements with classic geodetic measurements (tacheometry, GPS) to obtain the so-called georeferencing with an accuracy of more than $10 \mathrm{~mm}$. However, this does not change the positive response of the scanning technology that is increasingly being implemented.

However, this indicates the usefulness of the so-called multisensory, i.e. the use of research with the use of various types of measuring instruments. They show the synergy effect that allows for a significant increase in knowledge about the tested object. The authors [22] emphasize the importance of an integrated approach to the analysis and understanding of archaeological contexts in order to document what is still tangible and to recreate their original features and changes. You can then talk about 3D, 4D, etc. analysis, where the basis for locating information obtained from other measurement sensors are spatial data obtained by geodetic techniques (eg TLS). An example of such applications is the combination of static terrestrial scanning (TLS) and mobile aerial scanning (ALS) [23, 24], integration with the so-called texture mapping (photogrammetric techniques) $[25,26]$ or the simultaneous use of portable X-ray Fluorescence Spectroscopy ( $\mathrm{PXRF}$ ), and photogrammetric techniques to evaluate monuments from the Byzantine era [27].

Thanks to such data acquisition, it is possible to create metric 3D models in the form of raw point clouds, but the biggest advantage is the possibility of reconstruction by 3D modeling using surface structures (triangulation and grid) and combinations of solids. Examples of such an approach are the virtual reality modeling and visualization of the Palermo Cathedral [28], the automatic algorithm for creating models of buildings [29] and objects such as historic monuments [30] and ending with the three-dimensional visualization of Palazzo Raimondi in Cremona [31]. Such modeling is not an end in itself. It is also used for strictly construction purposes, enabling the reconstruction of the geometry of buildings as part of Building Information Modeling (BIM), which is now becoming a comprehensive database of information 
about existing buildings (including historic ones), as well as designed objects. This is discussed in more detail in publications $[18,19,32]$.

Raw and processed data can also be used to determine the deformation of historic buildings, resulting not only from the aging process, devastation (war) but also due to the influence of the environment (earthquakes, floods, etc.). Few examples of such analyzes are publications $[20,31,33,34]$ in which the behavior of the structure in a landslide area was examined, deviations from the ideal geometric condition or the load of arched structures and beam vaults were determined. These publications testify to the need and possibility of performing such advanced analyzes based on the increasingly used laser scanning. Thus, the following article is a presentation of the possibility of a geodetic look at the analysis of deformation of a historic object. The article [35] presents analyzes of a neo-gothic church subjected to deformations in the mining area, while the issue of the disclosure of deformation of the wooden structure was discussed.

\section{Description of the inventoried object}

The subject of the research of this thesis is a historic, wooden church dedicated to St. Szczepan (Stephen) (Fig. 1), located in Mnichów - a village in the Świętokrzyskie Province. It is one of the few original wooden monuments that have been preserved to this day, as wood is a material susceptible to harmful biological and atmospheric factors. The architectural object in question has a dome with two towers in the facade and unique Rococo interiors, which have been kept in a uniform style.

The date of creation of this religious building is unfortunately unknown. Most sources state that it was erected in the 18th century. According to a study by Roman Mirowski Wooden churches and bell towers of the Świętokrzyskie Land [36] in 1823, the monk's church ceased to be a filial church of the Mokrsko parish, which means that the church already existed. Wacław Jaskłowski [37] claimed that the church was built in 1731, although the foundation act was dated February 13,1770, and the founder was Stefan Dunin Wąsowicz. In turn, in 1930, Father Jan Wiśniewski stated in his work "Historical description of the church, cities, monuments and memorabilia in Jędrzejów" [38] that the church was built in 1754 and its founder was priest Maciej Łubieński, who in 1754 donated funds for its construction.

The construction of the church in Mnichów is very well thought out and homogeneous in terms of architecture. The first entries describing the church in Mnichów can be found in the Inventory fundi instructi [39]. They show that the church was built of larch wood, was covered with shingles and had two entrances. The main entrance with pine doors was preceded by a stone staircase. The smaller side entrance was also closed with a double door made of pine. The floor in the church was made of boards. The church also has four wooden altars and simple nine-voice organs located in the choir. In the basement of the church there is a brick chapel, whose vault is supported by columns and pillars. The chapel was called the second church. It was called the Sepulcher of Christ. In 1903-1917, the roof covering was replaced with shingles with sheet metal. In 2014, conservation of damaged formwork made of larch wood began. 
The church was built of larch wood. It has a log construction, which is covered with larch planks on the outside. The church is oriented, which means that the altar wall faces east. It is laid on a Latin cross plan (Fig. 2a). It has a sacristy, two porches and chapels of Saint Stanislaus Kostka on both sides of the presbytery. Above the intersection is an octagonal dome, which has four rectangular windows in Baroque frames. Under the dome there is a slender, octagonal lantern, which is covered with an onion-shaped helmet. The rectangular west facade is crowned with a triangular pediment, surrounded by two four-sided towers with zinc sheet roofs with lanterns.

In the northern part of the transept a Rococo altar was set up (Fig. 3), which is entirely made of larch wood. There is a picture of the Crucified Christ with a figure of the Mother of God kneeling at the foot of the cross, embracing him with his left hand. On the sides of the altar on high pedestals are placed two rococo sculptures made of linden wood, representing the Virgin Mary and Saint John the Evangelist. In the crowning of the altar is the figure of God the Father sitting on the clouds.

On the eastern side of the interior there is a music choir (Fig. 4). It is supported on slender, tall, wooden carved columns made in the Corinthian style. The organ prospectus placed on the choir is decorated with a rococo ornament.

Mnichow parish church of Saint Stephen is a very valuable monument of Polish, wooden, religious architecture. This is one of the few, well-preserved wooden temples in Poland. The Mnichow church is not only an object that can be seen and admired, but is also a place of prayer and celebrating the sacraments. However, it requires systematic building control, in which the geodesic-architectural inventory plays an important role.

\section{Methods}

\section{Geodetic inventory measurement technology}

Inventory of the wooden church of St. Szczepana in Mnichów was made using laser scanning using the Zoller \& Froehlich Imager $5010 \mathrm{C}$ phase laser scanner. It enabled measurements to be made with very high accuracy $( \pm 5 \mathrm{~mm}$ ), which allowed for a very detailed mapping of the measured object. This method allows obtaining a large amount of data with a relatively small amount of time, and at the same time is a non-invasive method, working in the field of near infrared, which in the case of a historic building with a lot of old polychroms is a key issue.

Measuring an object using a laser scanner involves measuring the distance and angle between the device and the target. Phase scanners use the phenomenon of phase shift. They constantly send infrared waves towards the rotating mirror of the scanner. Infrared rays are reflected from the mirror and are directed towards the object being measured, from which they are reflected and return to the scanner. Based on the phase shift of the infrared radiation wave that returns to the scanner, the distance is calculated. Thanks to the horizontal movement of the scanner head and the vertical rotation of the mirrors, it is possible, by taking into account the rotation angles counted by the scanner's stepper motors, to calculate the $X, Y, Z$ 
coordinates of the measured points, for which the value of the reflected laser light is additionally stored. For precise measurement of distances, the laser beam is divided into three components with different modulation lengths. The set of all these points is the so-called cloud the points that represent the surfaces from which the laser beam was reflected.. Each cloud point can also have RGB colour values assigned to it, which correspond to the colours recorded by the photos taken by the scanning device. Common points are used to orient the data obtained from several measurement stations, which are the so-called adaptation points for spatial transformation. Most often they are reference spheres or disks, but they can be other uniquely identifiable elements of existing buildings (points, edges, surfaces). The positioning of positions during the measurement session has an impact on the measurement efficiency. This becomes particularly important when using this method in the interiors of historic buildings, which are often tight and have complex geometry. This prevents free placement of stations and signals, as there is a risk of damage to the inventory object.

\section{Results}

\section{Church inventory}

The measurement according to the project was divided into 3 stages. At all stages, measurements were supplemented with digital photos that were taken using the built-in camera so that it would be possible to apply the texture to the resulting point cloud later. First, the measurement was carried out in the underground part of the building, which is the chapel of Christ's grave (Fig. 5). This level consists of 12 rooms. The second stage was the measurement of the main floor of the church of St. Stephen's and rooms on its level (Figs. 3, 4 and 6) and two positions in the choir, as there are two additional rooms. The final stage was the measurement of the object from the outside.

A total of 30 point clouds were obtained from the measurement. The $Z+F$ Laser Control 8.8.1 program was used to connect them. The scans were combined in two stages. The first of them contained 22 scans made inside the building, while the second one contained 8 scans, which were made when measuring the external part of the object. Satisfactory accuracy of a uniform point cloud was obtained, characterized by errors in the position of scanned points in a global system below $\pm 10 \mathrm{~mm}$. After performing procedures of filtering point clouds in terms of reflection quality, removing unnecessary elements and overrides, a uniform file was obtained containing scans made inside and outside the object. (Fig. 6a), from which the outline of the rooms of the lower and main floors of the church can be separated (Fig. 6b)

Figure 6 Point cloud representing the church from the outside (a) and a floor plan based on horizontal cross-sections through the point cloud (b).

According to analyzes, the church is: $27.75 \mathrm{~m}$ high, $695.50 \mathrm{~m}^{2}$ of total building area and $4150 \mathrm{~m}^{3}$ of volume. Room volumes were determined based on the area determined in AutoCad 2020 and the average height determined based on the floor and floor identification based on CloudCompare. An example of 
conducted analysis for room D shown in Fig. 7 and detailed results for individual rooms are presented in Table 1.

Table 1

Geometric characteristics of the church's rooms

\begin{tabular}{|lllll|}
\hline Room & $\begin{array}{l}\text { Circumference } \\
{[\mathrm{m}]}\end{array}$ & $\begin{array}{l}\text { Height } \\
{[\mathrm{m}]}\end{array}$ & $\begin{array}{l}\text { Area } \\
{\left[\mathrm{m}^{2}\right]}\end{array}$ & $\begin{array}{l}\text { Volume } \\
{\left[\mathrm{m}^{3}\right]}\end{array}$ \\
\hline P (underground) & 221,33 & 3,47 & 320,87 & 1113,42 \\
\hline A (main nave) & 83,91 & 17,77 & 260,17 & 2556,3 \\
\hline B & 16,66 & 4,18 & 17,5 & 73,16 \\
\hline C & 16,1 & 3,75 & 16,34 & 61,26 \\
\hline D & 23,17 & 3,99 & 26,7 & 106,53 \\
\hline E & 21,65 & 3,94 & 21,64 & 85,25 \\
\hline F & 16,13 & 4,76 & 16,19 & 77,06 \\
\hline G & 16,04 & 4,62 & 16,01 & 73,97 \\
\hline
\end{tabular}

As a result of the inventory work carried out, a virtual replica of the building was created in the form of a 3D model, which is shown in Fig. 7. In order to reproduce the colour of the outer walls of the church, RGB colour obtained from simultaneously taken photos was used.

\section{Analyzes of the geometric state}

To determine the condition of geometric invariance, a number of analyzes were performed based on the acquired uniform point cloud. Among other things, an analysis of the floor level of both floors was carried out, based on the measured points after the filtration process (removal of building elements) and thinning of the cloud. A matrix of points of the tested surfaces at regular intervals of $0.05 \mathrm{~m}$ was obtained, which was then subjected to the process of determining the floor height changes in the CloudCompare program and controlling the interpolation of the contour lines in the Surfer® program using the Nearest Neighbours algorithm. Figure 8 presents hypsometric plans for the level of floors in the rooms of the underground chapel (Fig. 8a) and its ceiling (Fig. 8b) in the adopted system of local height.

Figure 7 Verticality of the floor of the underground chapel (a) and its ceiling (b) and the floor of the nave (c)

The maps presented in Fig. 8 indicate the diversity of levels of individual floors and most importantly, a change in their level in the same room can be observed. Unfortunately, due to the status of the monument, it was impossible to make measurements for covered structural elements (foundations), however, the changes in the level shown in this way, which are within the limits of $5 \mathrm{~cm}$ in individual rooms can be considered statistically significant. The same conclusion can be drawn from the analysis 
of the level of the underground chapel ceiling. Similar procedures were also carried out for the nave floor. However, due to its very large construction elements of equipment that could not be removed and the fact that the boards covering the floor are not a structural element, but only a masking one, the height difference determined may not accurately reflect the levelness of the floor. However, it indicates the tendency of inclination in the west-south direction, as the ceiling of the underground part indicates.

An important aspect of the stability of a wooden structure is the verticality of the walls. Failure to comply with this condition may indicate areas with an increased risk of stress transmission and worsening of the unfavourable condition for the structural statics. The church in Mnichów has 14 external walls and they have been subjected to verticality analysis. The designations of the walls that have been measured are marked in Fig. 9. Similar to the floor level test, points belonging to individual walls were selected and points corresponding to window and door openings were removed. Then the point cloud was thinned out so that the minimum distance between points was $0.5 \mathrm{~m}$. In the analysis of contour plans, the local coordinate system of the building used local systems, in accordance with the tested planes, in which the flat coordinates referred locally to the tested plane and as an indicating coordinate for non-verticality, the value perpendicular to it was considered. It was found that the walls of the building are tilted west (towards the main entrance, opposite the altar) within $(6 \div 34 \mathrm{~mm} / \mathrm{m})$ and to the south $(9 \div 21 \mathrm{~mm} / \mathrm{m})$. Sample charts of vertical line isolation are presented in Fig. 8 and detailed data in Table 2.

Figure 8. Deviations from the vertical wall of the external walls of the structure - a) walls " $M$ " and " $F$ " on the west-east axis, b) walls " $B$ " and " $J$ " on the north-south axis 
Table 2

The value of the wall deviation from the vertical (wall markings in accordance with Fig. 8)

\begin{tabular}{|lllll|}
\hline Wall marking & Number of points & Height of walls [m] & Slope value [mm/m] & Tilt direction \\
\hline A & 49 & 3,63 & 21 & South \\
\hline B & 160 & 8,85 & 19 & South \\
\hline D & 63 & 3,67 & 13 & South \\
\hline E & 94 & 8,78 & 9 & South \\
\hline F & 45 & 8,73 & 6 & West \\
\hline G & 150 & 8,97 & 19 & West \\
\hline H & 74 & 8,68 & 17 & West \\
\hline I & 75 & 8,93 & 9 & South \\
\hline J & 60 & 3,30 & 17 & South \\
\hline K & 151 & 8,76 & 16 & South \\
\hline L & 46 & 3,51 & 11 & South \\
\hline M & 24 & 3,43 & 26 & West \\
\hline N & 162 & 8,87 & 35 & West \\
\hline
\end{tabular}

The reported deviations from the vertical indicate that the structure is tilting southwest. The resultant value cannot be directly indicated here, because these walls are not connected into one monolith.

Nevertheless, a tendency to south-west swing has been shown. It should be remembered that the church was built in the 18th century from larch wood, which is considered to be the most durable and resistant to deformations caused by weather conditions and the passage of time. However, the inclination of the walls may have been influenced by the way the building was erected and the lack of precise technology for preparing elements of the wooden structure.

One of the elements of the internal structure, which indicates potential deformation is the analysis of verticality of the columns supporting the floor on both floors.. In the main nave they support the choir (Fig. 4), while in the underground chapel they support the ceiling (Fig. 5). To determine the values of the inclination of the columns, it was necessary to determine their height, as well as the values of the shift of the centres of the columns in the XY plane. It was based on extreme cross-sections for which the geometrical centres of each column contour were determined at individual height levels. The results of the calculations are presented below in Fig. 10.

The columns in the underground chapel of the Holy Sepulchre are tilted to the north-west. The northern column has a greater inclination, i.e. $16 \mathrm{~mm} / \mathrm{m}$. The columns located in the nave of the church lean only 
to the west. The northern column also has a greater inclination, i.e. $26 \mathrm{~mm} / \mathrm{m}$. Also these analyses indicate that the inclination of the structure at the level of the main nave is predominant in the western direction, similarly to the external walls of the church structure.

The church's structure is reinforced by a roof truss, which cooperates with elements of the wooden skeleton in a much more active way than in modern concrete and brick constructions. For this reason, checking the shape of the truss, by analyzing its symmetry, may allow additional inference regarding the condition of the entire structure. For this purpose, the analysis of the levelness of the roof edges (ridge) in the longitudinal and transverse direction and the analysis of the roof slope inclination were made. The ridge slope was calculated on the basis of the distance between the characteristic points (Fig. 11) and the height difference between them using trigonometric functions.

Maximum gradients were found on the B-A section (+38 mm / m) (Fig. 11) but also on the north-south direction for the E-F section $(-40 \mathrm{~mm} / \mathrm{m})$. Roof slopes analyzed in cross-sections indicate their warping and torsion of their planes, however, not exceeding $\pm 1.4 \%$ (up to $70 \mathrm{~mm} / 5 \mathrm{~m}$ ).

\section{Discussion}

The proposed scope of the analysis of the geometric condition of the historic church is a significant fragment of the possible research. However, in conditions where it is an object used daily for religious activity, it is difficult to talk about interference in the structure of the equipment and its even temporary disassembly for the purposes of other types of research. For this reason, the selected range of measurements based on laser scanning seems to be the optimal technology, guaranteeing an appropriate level of accuracy of the inventory performed. The measurement technique used was based on the socalled reference points (targets) that allowed for proper and unambiguous creation of a 3D model of the entire church. Note that "targets" cannot be used in all conditions. Then you should consider the use of such software that enables the merging of point clouds with the "cloud to cloud" algorithm. Then there is no need to use reference points and the merging is based on automatically determined dependencies between points, planes and edges detected by the algorithm $[40,41]$ on the analyzed scans. However, there is then no guarantee that the accuracy of the resulting spatial model will be at the same level of accuracy as using "targets". Due to the possibility of registering additional attributes assessing the structure, apart from the RGB camera, an infrared camera can be used, which will allow the assessment of the energy stability of the facility. It is very important from the point of view of preventing the degradation of the structure and equipment of such a historic building, thanks to the detection of the socalled thermal bridges showing areas of heat transfer through the structure. Unfortunately, in the presented study, the author did not have access to such a device, but he sees the legitimacy of using such a research method in the evaluation of subsequent historic buildings. A wooden church is a specific object for the analysis of the geometric state. This is due to the fact that the wood is susceptible to the transmission of deflections and deformations even under conditions of large deformation. Therefore, it is difficult to determine the safety threshold and each such object should be treated individually. The presented results of the assessment of the geometric condition by means of laser scanning allow to refer 
to the relationship in the form of parallelism, horizontality, verticality of the structure elements, which in most cases gives a sufficient basis for inferring about the safety of the structure. However, as mentioned earlier, the failure to maintain these relations in the case of a wooden structure does not immediately indicate a condition that threatens its safety. In such a case, it cannot be unequivocally stated, as it was presented in the article on concrete engineering [34], that the increased load on the beams of the wooden structure appears almost immediately in the form of deformation and is additionally included in the functional relationship. The analysed structure has not been rebuilt since its construction and despite the imperfections shown in the article, it is in good condition.

\section{Conclusions}

St Stephen's Church in Mnichow is about 250 years old. This means that it is a fairly young monument. However, due to the material from which it was built and the technology that was available then it deserves admiration. It is characterized by high accuracy of execution, especially considering the baroque equipment. All of its details were created with great care. To carry out the stocktaking, laser scanning was used as a measurement technology. It made it possible to conduct non-invasive tests of the geometrical state of the entire structure without interfering with the arrangement of equipment elements. The performed laser measurements together with the simultaneously conducted photo session allowed for the creation of geodetic and architectural documentation but also for digital preservation of the current state of the monument. Certainly, digital spatial models in the form of a point cloud and a solid model are also helpful in this respect, allowing for multiple analyses and comparison of their results in the case of periodical surveys.

The current geometrical condition showed existing imperfections in the shape of the church structure, the surface of floors, walls and roof slope. They are probably the result of imperfections in the art of construction from over 200 years ago, but also of the manifesting process of deformation due to the impact of unidentified external conditions. The confirmation of this hypothesis is the dominant direction of the structure's tilt towards the west, determined in several analyzes. Regardless of the identified imperfections in the structure's geometry, the condition of the building should be considered good, despite the fact that in recent years the church has not undergone any renovation works that could have affected the change of its condition and geometry. Due to the value of the monument, it is recommended to remeasure it to check if the church's geometry has changed. On the basis of the performed analyses, it is not possible to clearly state whether the changes in the church's geometry are progressing over time, as there is no documentation of the church's measurements from previous years.

\section{Declarations}

- Availability of data and materials

The datasets used and/or analysed during the current study are available from the author on reasonable request. 
- Competing interests

The author declare that they have no competing interests

- Funding

The Faculty of Mining Surveying and Environmental Engineering AGH UST own funds were used

- Authors' contributions - not applicable

- Acknowledgements

- Authors' information

The author specializes in the use of mining geodesy and deformation analysis of objects located in areas subject to deformation, especially under the influence of mining exploitation. For over 10 years, he has been using laser scanning in the analysis of deformation of buildings and mining shafts.

\section{References}

1. Technical Guidelines G3 Inventory of urban complexes, green areas and architectural objects. Wytyczne Techniczne G3.4, Inwentaryzacja zespołów urbanistycznych, zespołów zieleni i obiektów architektury.

2. Kurzątkowski M. Mały słownik ochrony zabytków, (Little Dictionary of Monuments Protection),Warszawa. MKiS 1989.

3. Falkowski P, Uchański J. Sörensen L.; "The Problem of Standardization of Terrestrial Laser Scanning Techniques for Architecture Inventory Purposes" Archives of Photogrammetry, Cartography And Remote Sensing. Vol. 18, 2008.

4. Davis A, Belton D, Helmholz P, Bourke P, McDonald, Jo. Pilbara rock art: laser scanning, photogrammetry and 3D photographic reconstruction as heritage management tools. Heritage Science. 2017;5:25. doi:10.1186/s40494-017-0140-7.

5. Liu R, Shi G, Ji F, "Ancient architecture reconstructing based on Terrestrial 3D Laser Scanning technology," The 2nd International Conference on Software Engineering and Data Mining, Chengdu, 2010, pp. 285-288.

6. Xie Rui C, Xiaojun, Hongfei Z, "Terrestrial Laser Scanning for the digital protection of historical architecture," 2010 Second IITA International Conference on Geoscience and Remote Sensing, Qingdao, 2010, pp. 246-249. doi: 10.1109/IITA-GRS.2010.5603133.

7. Yin Y, Antonio J. Application of 3D laser scanning technology for image data processing in the protection of ancient building sites through deep learning. Image Vis Comput. 2020;102. doi:10.1016/j.imavis.2020.103969.

8. Bai C, Wang Q, Misapplications of 3D laser scanning in metric survey of historic buildings, 2011 International Conference on Remote Sensing, Environment and Transportation Engineering, Nanjing, 2011, pp. 1354-1357.doi: 10.1109/RSETE.2011.5964532. 
9. Zhang R, Wang Y, Song D. Research on 3D Reconstruction Using Laser Scanning Data Acquired from Ancient Architecture, 2009 First International Conference on Information Science and Engineering, Nanjing, 2009, pp. 2145-2148.doi: 10.1109/ICISE.2009.928.

10. Webb N, Buchanan A, Tracing the Past: a digital analysis of the Lady Chapel vaults at Ely cathedral, 2018 3rd Digital Heritage International Congress (DigitalHERITAGE) held jointly with 2018 24th International Conference on Virtual Systems \& Multimedia (VSMM 2018), San Francisco, CA, USA, 2018, pp. 1-4. doi: 10.1109/DigitalHeritage.2018.8810054.

11. Barba S, De Feo E, D'Auria S, Guerriero L, Survey and virtual restoration: The Castle of Magacela (Spain), 2012 18th International Conference on Virtual Systems and Multimedia, Milan, 2012, pp. 641-644.doi: 10.1109/VSMM.2012.6365997.

12. Pattee A, Höfle B, Seitz $C$, Integrative 3D recording methods of historic architecture Burg Hohenecken castle from southwest Germany, 2015 Digital Heritage, Granada, 2015, pp. 95-98. doi: 10.1109/DigitalHeritage.2015.7413843.

13. Spring AP, Peters C, Minns T. Using Mid-Range Laser Scanners to Digitize Cultural-Heritage Sites, in IEEE Computer Graphics and Applications. May-June. 2010;Vol. 30(3):pp. 15-9. doi:10.1109/MCG.2010.62.

14. Guidi G, Russo M, Angheleddu D, Zolese P. A virtual connection between past and present: The digital revival of Cham's Architecture (Vietnam), 2012 18th International Conference on Virtual Systems and Multimedia, Milan, 2012, pp. 361-368. doi: 10.1109/VSMM.2012.6365946.

15. Hess M, Petrovic V, Meyer D, Rissolo D, Kuester F. Fusion of multimodal three-dimensional data for comprehensive digital documentation of cultural heritage sites, 2015 Digital Heritage, Granada, 2015, pp. 595-602. doi: 10.1109/DigitalHeritage.2015.7419578.

16. Yintao Shi, Cheng X, Study of architecture modeling method and accuracy based on laser scanning, 2010 International Conference on Computer Application and System Modeling (ICCASM 2010), Taiyuan, 2010, pp. V11-176-V11-180. doi: 10.1109/ICCASM.2010.5623233.

17. Ghazali R, Sukri AEziwanE, Abd Rahman Abd Latif, Abd Rauf Abd Rasam, Latif Z. A. and Samad A. M., Evaluating the relationship between scanning resolution of laser scanner with the accuracy of the 3D model constructed, 2011 IEEE International Conference on Control System, Computing and Engineering, Penang, 2011, pp. 590-595. doi: 10.1109/ICCSCE.2011.6190595.

18. Rebolj D,. Pučko Z, Čuš Babič N, Bizjak M, Mongus D. Point cloud quality requirements for Scan-vsBIM based automated construction progress monitoring. Autom Constr. 2017;84:323-34. https://doi.org/10.1016/j.autcon.2017.09.021. ISSN 0926-5805.

19. Sanhudo L, Ramos NMM, Martins JP, Almeida RMSF, Barreira E, Lurdes Simões M, r Cardoso V, A framework for in-situ geometric data acquisition using laser scanning for BIM modelling, Journal of Building Engineering, Volume 28, 2020, 101073, ISSN 2352-7102, https://doi.org/10.1016/j.jobe.2019.101073.

20. Wojtkowska M, Kedzierski M, Delis P. Validation of terrestrial laser scanning and artificial intelligence for measuring deformations of cultural heritage structures. Measurement. 2021;167. 
doi:10.1016/j.measurement.2020.108291.

21. Di Yajing, Chengjun B, "Application scope of the Terrestrial Laser Scanner in measured survey on architectural heritages," 2011 International Conference on Electric Technology and Civil Engineering (ICETCE), Lushan, 2011, pp. 2954-2957. doi: 10.1109/ICETCE.2011.5775866.

22. Galli $M$, Inglese $C$, Ismaelli $T$, Griffo $M$, Rome under Rome: survey and analysis of the east excavation area beneath the Basilica lulia, 2018 3rd Digital Heritage International Congress (DigitalHERITAGE) held jointly with 2018 24th International Conference on Virtual Systems \& Multimedia (VSMM 2018), San Francisco, CA, USA, 2018, pp. 1-4. doi: 10.1109/DigitalHeritage.2018.8810042.

23. Kwoczynska B, Piech I, Polewany P, Gora K. Modeling of Sacral Objects Made on the Basis of Aerial and Terrestrial Laser Scanning, 2018 Baltic Geodetic Congress (BGC Geomatics), Olsztyn, 2018, pp. 275-282. doi: 10.1109/BGC-Geomatics.2018.00059.

24. Cheng Wang C, Wen Y, Dai S, Yu M, Liu. Urban 3D modeling with mobile laser scanning: a review, Virtual Reality \& Intelligent Hardware, Volume 2, Issue 3, 2020, Pages 175-212, ISSN 2096-5796, https://doi.org/10.1016/j.vrih.2020.05.003.).

25. Valenti GM, Romor J, Image Based Modeling, 3D Laser scan \& Gigapixel survey for the documentation of Carlo Lucangeli's Flavian Amphitheater wooden model, 2018 3rd Digital Heritage International Congress (DigitalHERITAGE) held jointly with 2018 24th International Conference on Virtual Systems \& Multimedia (VSMM 2018), San Francisco, CA, USA, 2018, pp. 1-4. doi: 10.1109/DigitalHeritage.2018.8810068.

26. Carpiceci M, Angelini A, Looking for the full scan: S. Zenone chapel, 2018 Metrology for Archaeology and Cultural Heritage (MetroArchaeo), Cassino FR, Italy, 2018, pp. 345-350. doi:

10.1109/MetroArchaeo43810.2018.9089799.

27. Cosentino A, Sgarlata M, Scandurra C, Stout S, Galizia M, Santagati C, Multidisciplinary investigations on the byzantine oratory of the Catacombs of Saint Lucia in Syracuse, 2015 Digital Heritage, Granada, 2015, pp. 137-140. doi: 10.1109/DigitalHeritage.2015.7419471.

28. Agnello F, The Cathedral of Palermo: From survey to historic interpretation, 2013 Digital Heritage International Congress (DigitalHeritage), Marseille, 2013, pp. 713-716. doi:

10.1109/DigitalHeritage.2013.6743824.

29. Huber D, Akinci B, Tang P, Adan A, Okorn B, Xiong X, Using laser scanners for modeling and analysis in architecture, engineering, and construction, 2010 44th Annual Conference on Information Sciences and Systems (CISS), Princeton, NJ, 2010, pp. 1-6. doi: 10.1109/CISS.2010.5464818.

30. Laing R, Leon M, Isaacs J, Visualization M: From 3D Scanned Data to a Holistic approach, an Application to the City of Aberdeen, 2015 19th International Conference on Information Visualisation, Barcelona, 2015, pp. 512-517. doi: 10.1109/iV.2015.91.

31. Cardaci A, Roberti GM, Versaci A, Palazzo Raimondi in Cremona: 3D survey and diagnostic tests for the knowledge of construction techniques and historical materials, 2015 Digital Heritage, Granada, 2015, pp. 181-184. doi: 10.1109/DigitalHeritage.2015.7419482. 
32. Tang P, Huber D, Akinci B, Lipman R, Lytle A. Automatic reconstruction of as-built building information models from laser-scanned point clouds: A review of related techniques. Automation in Construction Volume. November 2010;19, Issue 7:829-43.

33. Akib WAAWM, Tahar KN, Ahmad A, Slope gradient analysis at different resolution using terrestrial laser scanner, 2012 IEEE 8th International Colloquium on Signal Processing and its Applications, Melaka, 2012, pp. 169-173. doi: 10.1109/CSPA.2012.6194712.

34. Yang H, Xu X, Xu W, Neumann I. Terrestrial Laser Scanning-Based Deformation Analysis for Arch and Beam Structures. IEEE Sens J. 2017;17(15 July15):14, pp. 4605-11. doi:10.1109/JSEN.2017.2709908. no.

35. Lipecki T, Ligarska H, Zawadzka M. The influence of mining activities on the Church of St. Cross in Bytom-Miechowice. Reports on Geodesy Geoinformatics. 2018;105:7-18. doi:10.2478/rgg-20180002.

36. Mirowski R. Drewniane kościoły i dzwonnice Ziemi Świętokrzyskiej.(Wooden churches and bell towers of the Świętokrzyskie Region), Kielce. 2002.

37. Jaskłowski W. Z przeszłości jędrzejowskiego. Dominium Mnichów. (From the past of Jędrzejowski. Mnichów: Dominion of Mnichow); 1919.

38. Wiśniewski J; Historyczny opis kościołów, miast, zabytków i pamiątek jędrzejowskich. (Historical description of Jędrzejów churches, towns, monuments and mementoes), Marjówka. 1930.

39. Tkaczyk P. Kościół świętego Szczepana w Mnichowie, Zabytek drewnianej architektury sakralnej (Saint Stephen's Church in Mnichów, a monument of wooden sacred architecture), Kielce: Parafia św. Szczepana w Mnichowie. 2014.

40. Torre-Ferrero C, Llata JR, Alonso L, Robla S, Sarabia EG. 3D point cloud registration based on a purpose-designed similarity measure. EURASIP J Adv Signal Process. 2012;2012:57. doi:10.1186/1687-6180-2012-57.

41. Song P. Local voxelizer: A shape descriptor for surface registration. Computational Visual Media. December 2015;1(4):279-89. doi:10.1007/s41095-015-0019-z.

\section{Figures}




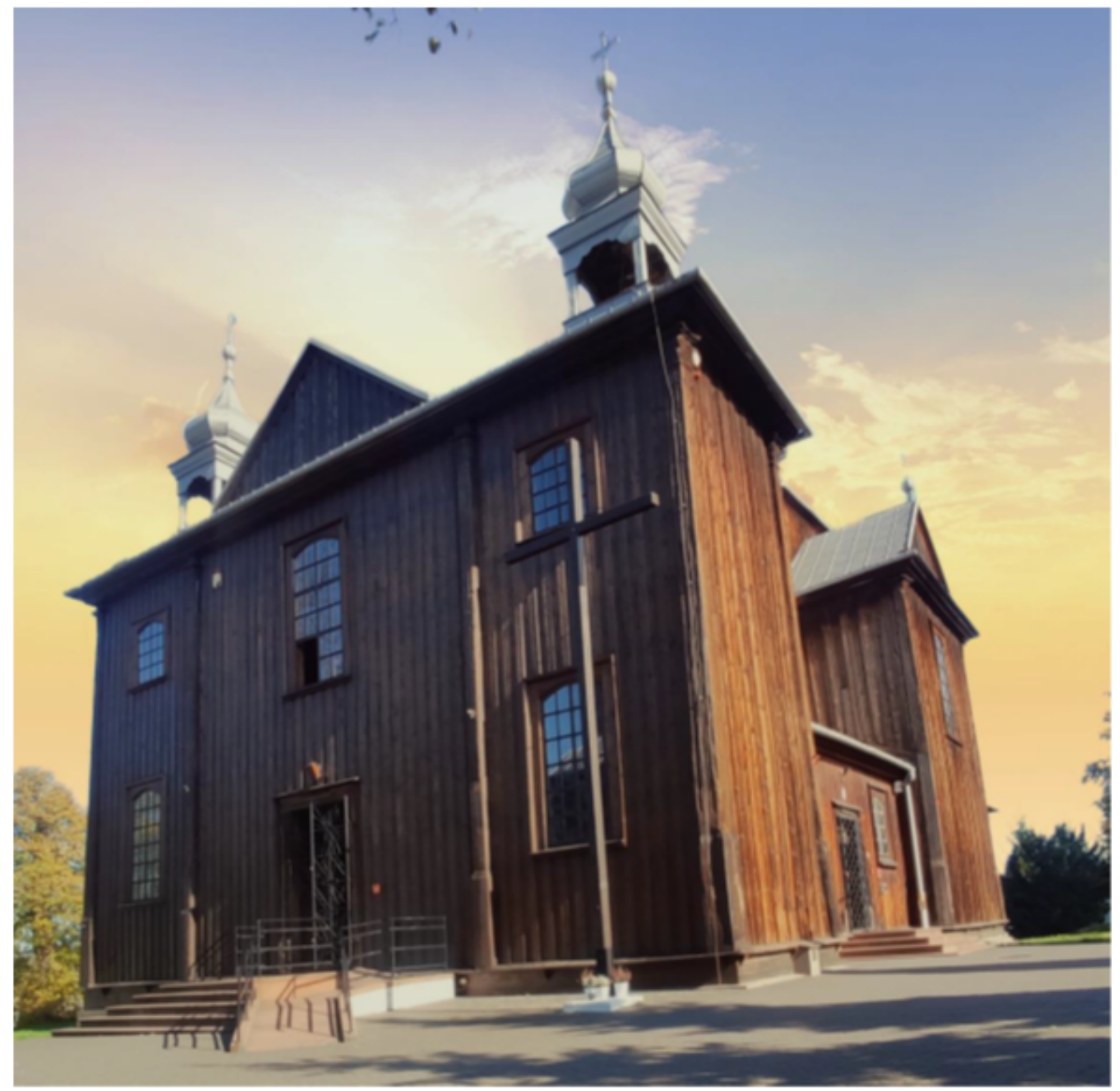

Figure 1

View of the church of St. Szczepan in Mnichów (source: private archive) 


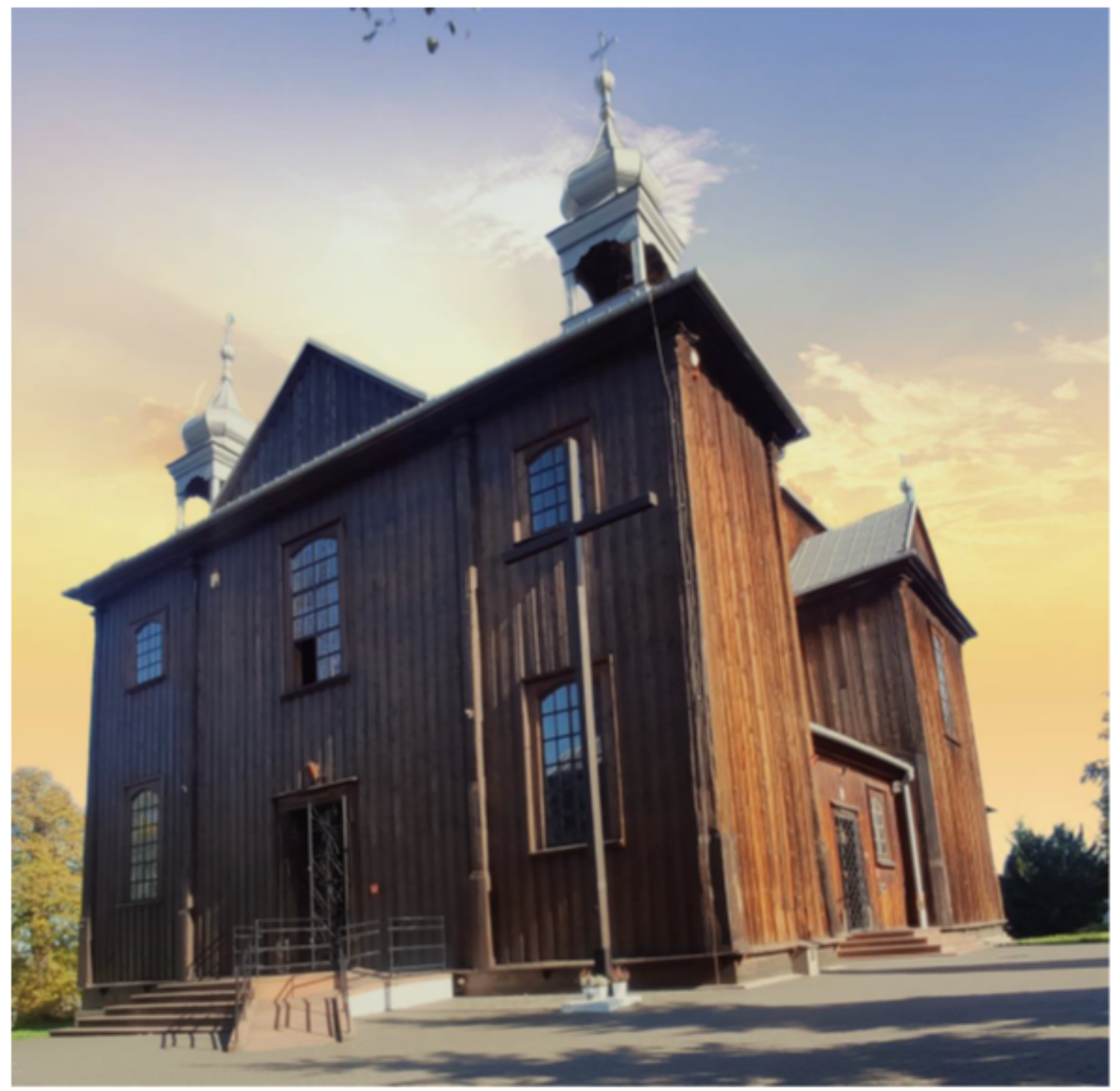

Figure 1

View of the church of St. Szczepan in Mnichów (source: private archive)
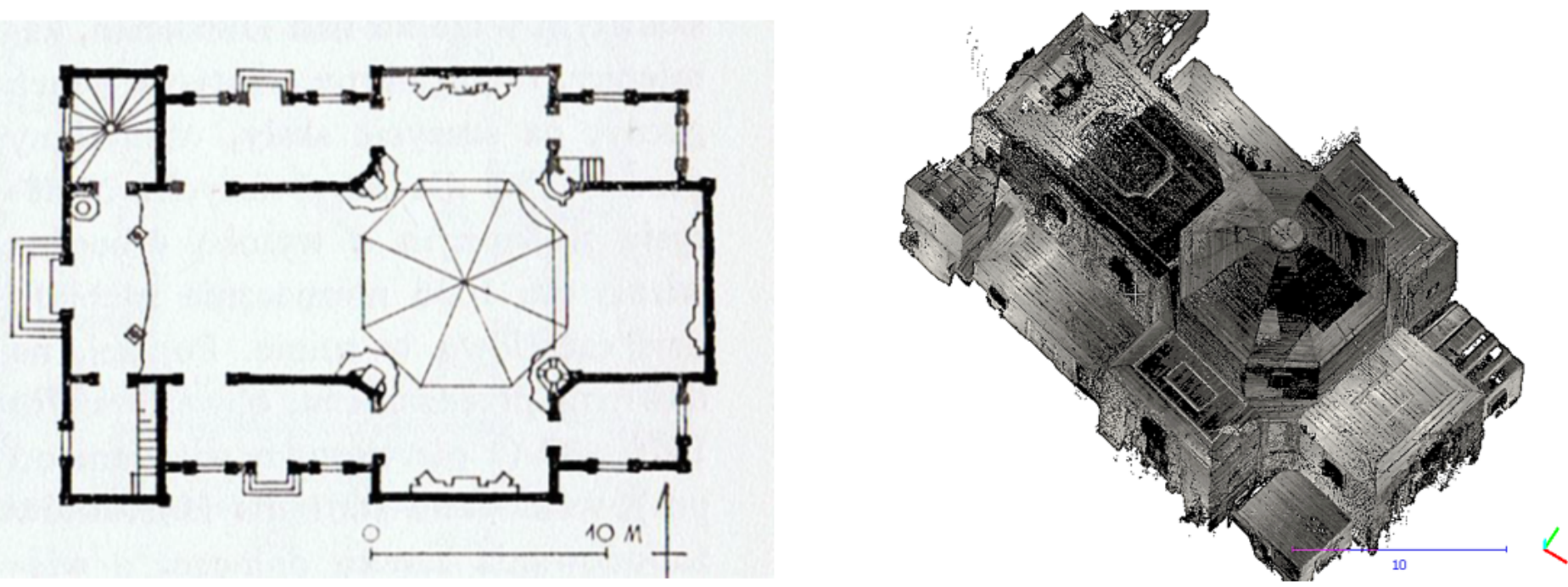
Figure 2

Plan of the church of St. Szczepan in Mnichów (a) (source: http://www.zabytkowekoscioly.net) and the scanned internal structure of the structure (b)
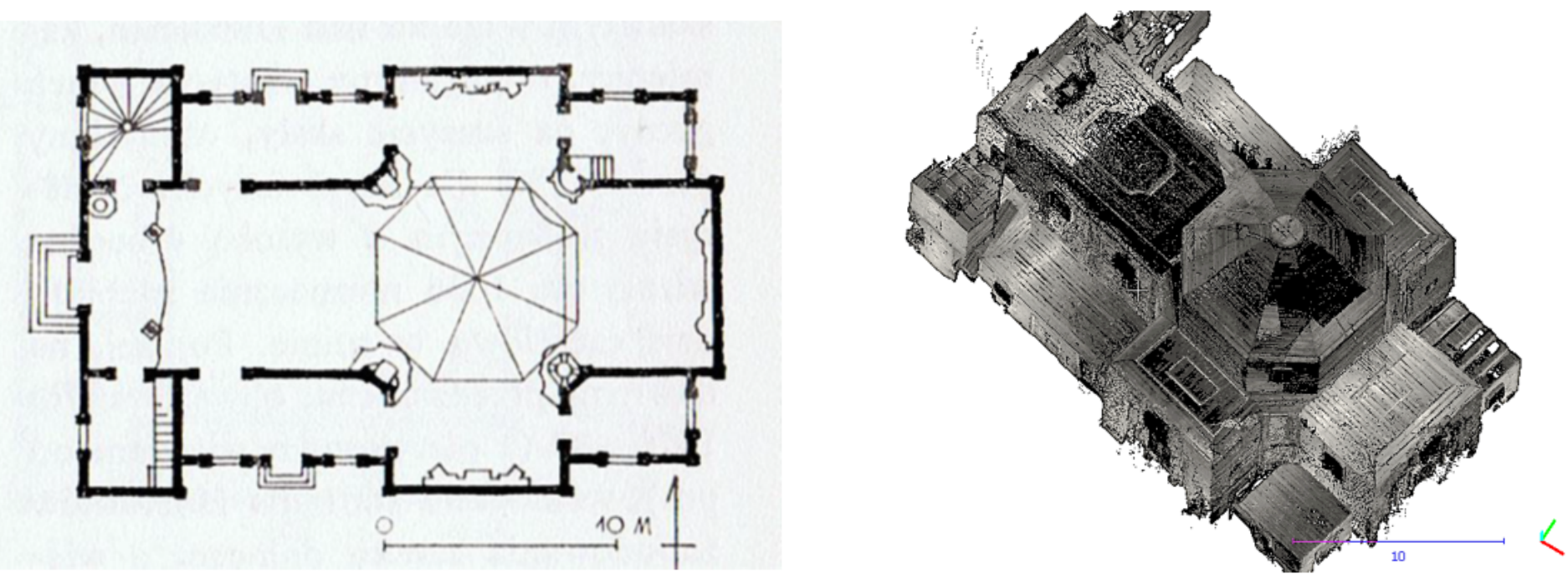

Figure 2

Plan of the church of St. Szczepan in Mnichów (a) (source: http://www.zabytkowekoscioly.net) and the scanned internal structure of the structure $(b)$
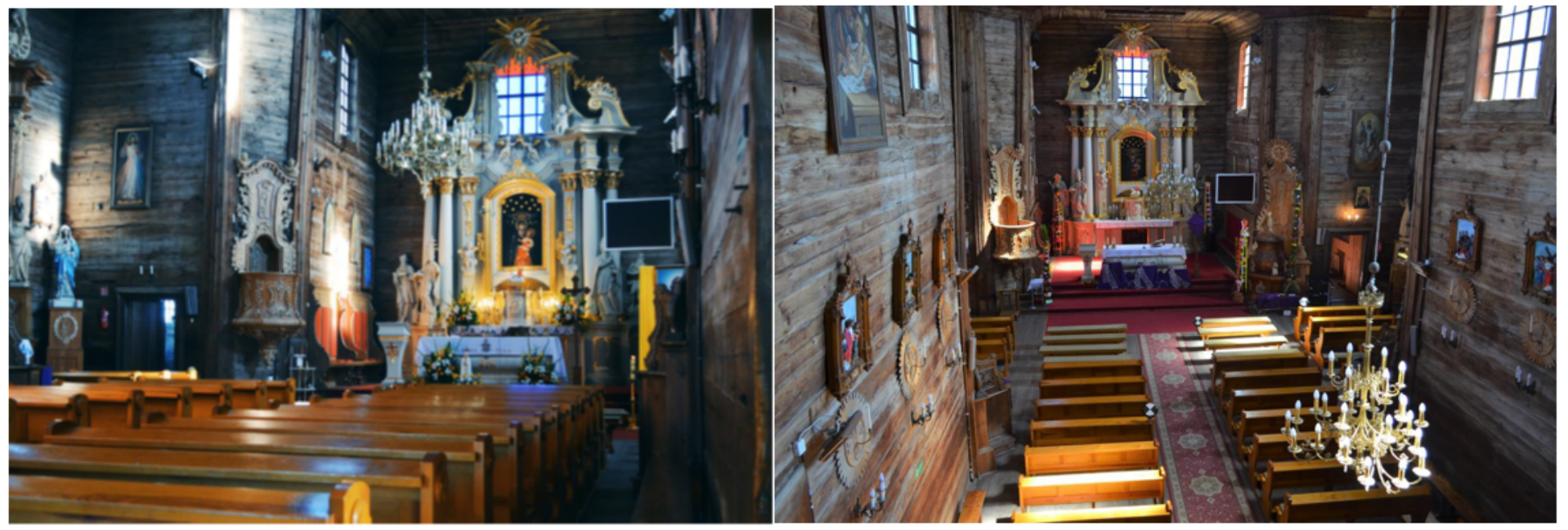

\section{Figure 3}

The interior of the church of St. Szczepan in Mnichów (source: private archive) 


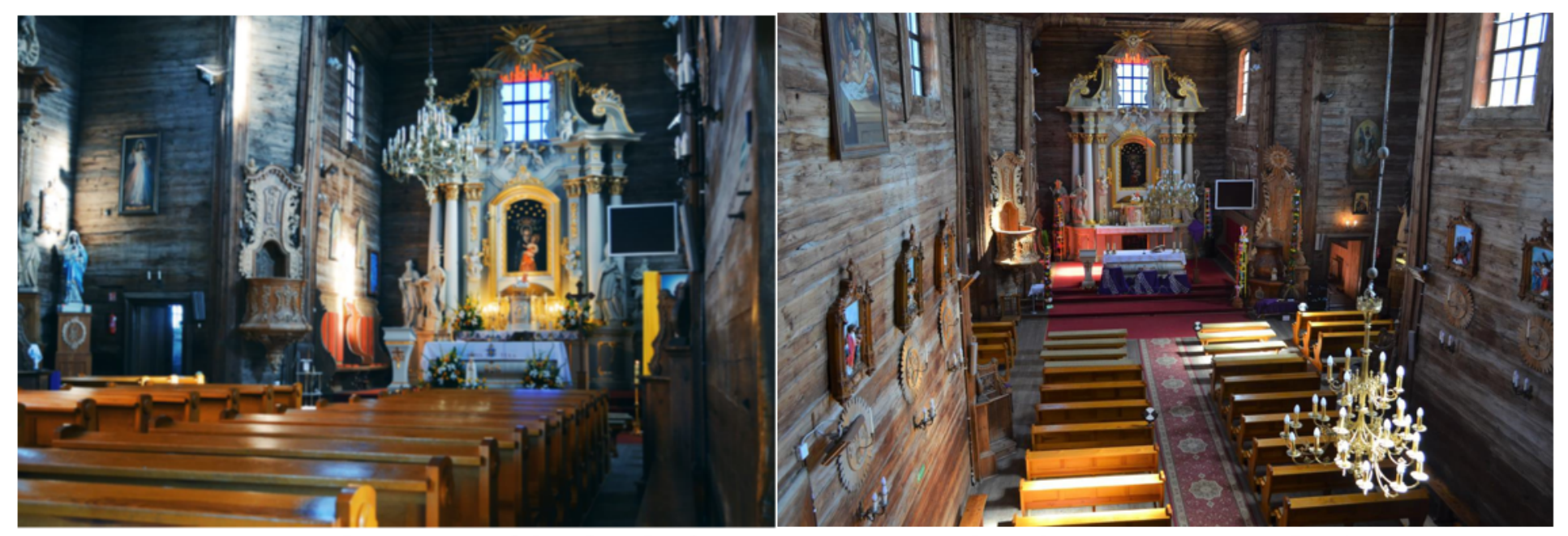

\section{Figure 3}

The interior of the church of St. Szczepan in Mnichów (source: private archive)

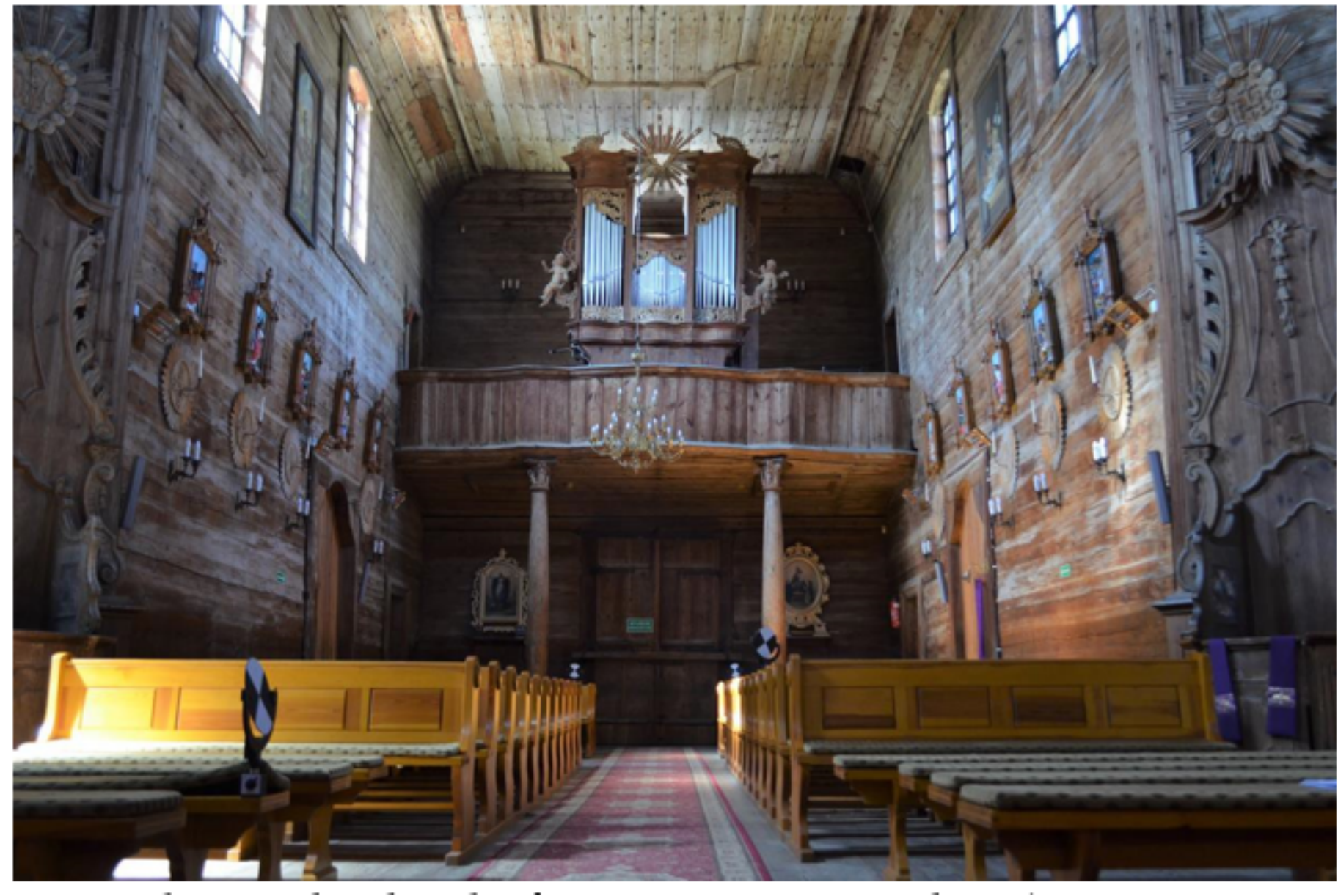

\section{Figure 4}

Music choir in the church of St. Szczepan in Mnichów (source: private archive) 


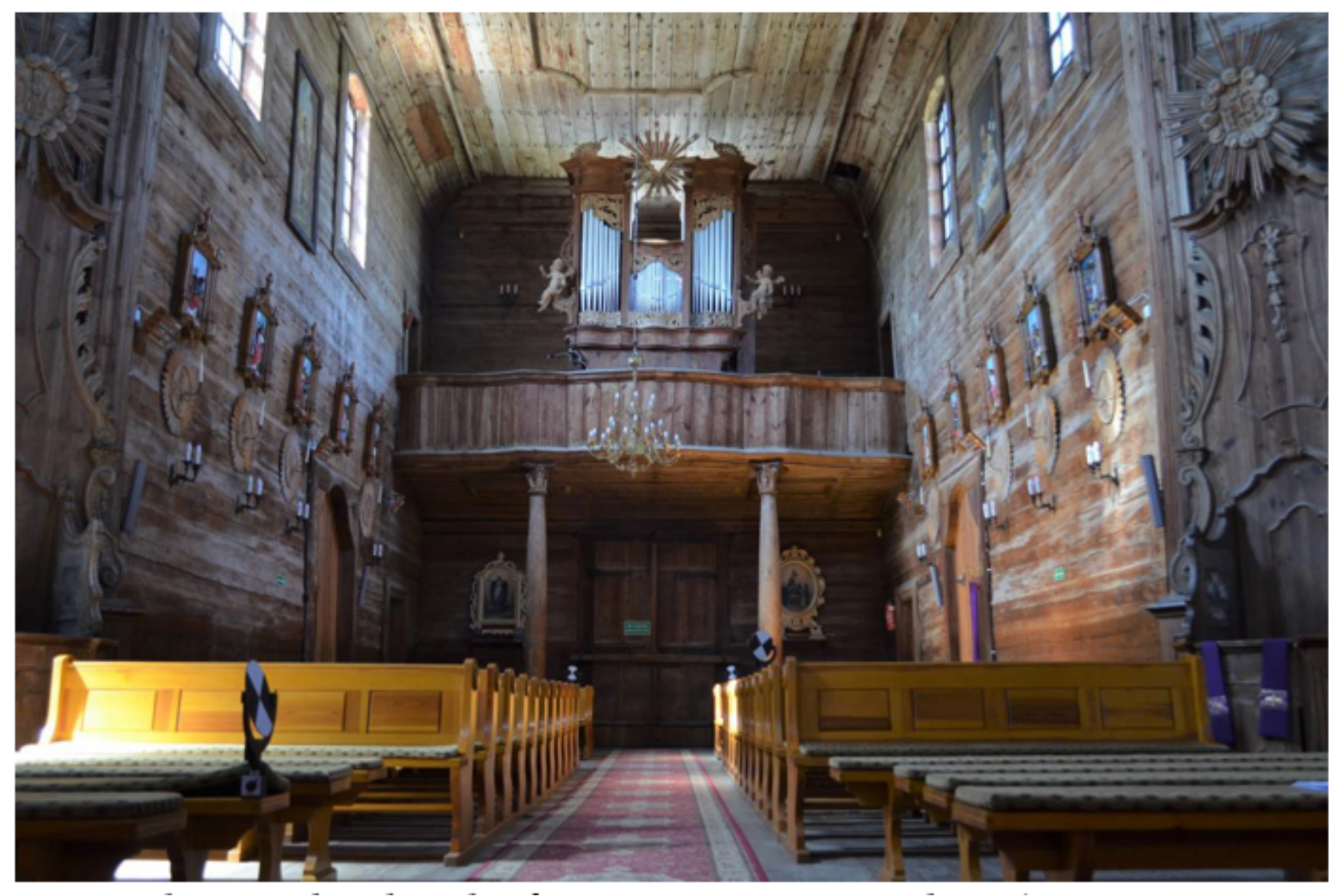

Figure 4

Music choir in the church of St. Szczepan in Mnichów (source: private archive) 


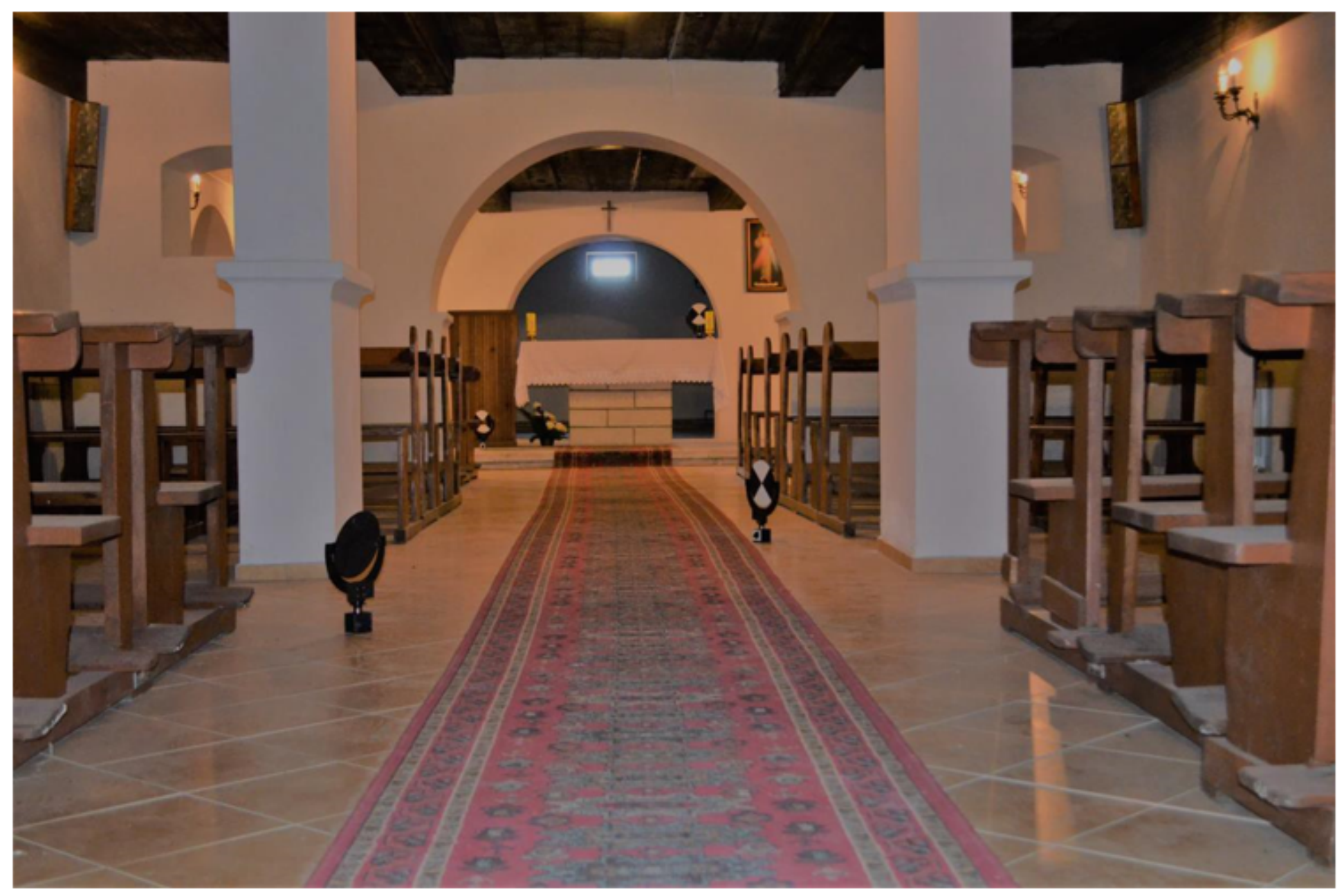

Figure 5

Measurement of the Chapel Tomb of Christ (source: private archive) 


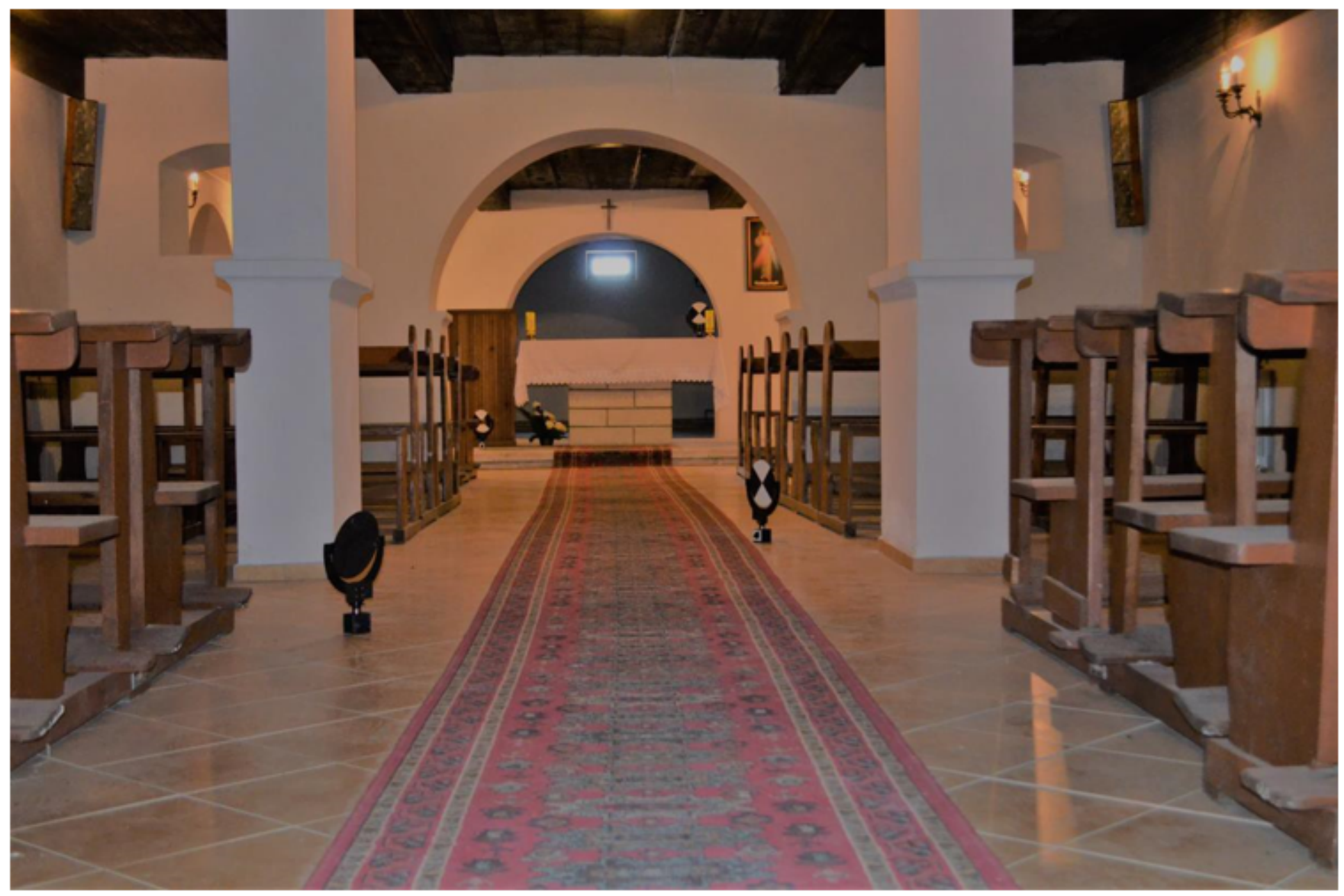

Figure 5

Measurement of the Chapel Tomb of Christ (source: private archive)

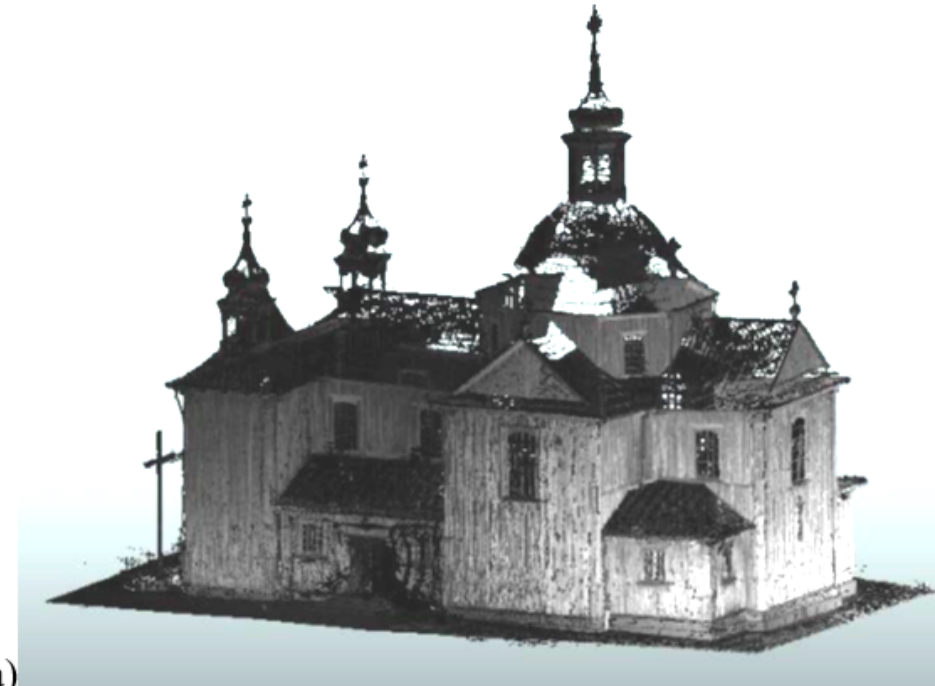

b)

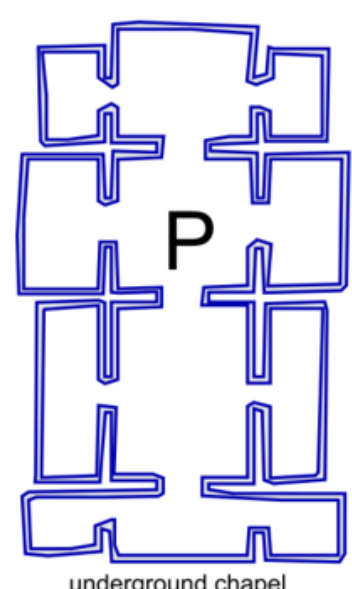

underground chapel

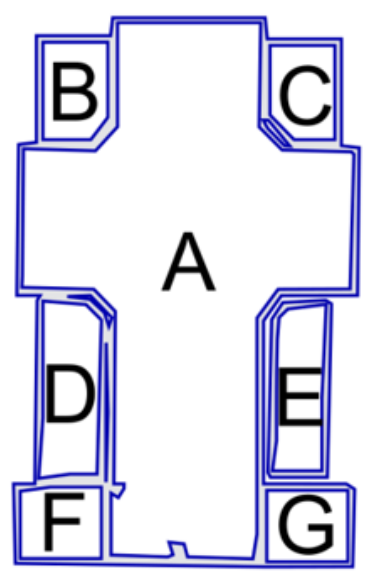

main floor and choir

\section{Figure 6}


Point cloud representing the church from the outside (a) and a floor plan based on horizontal crosssections through the point cloud (b).

a)

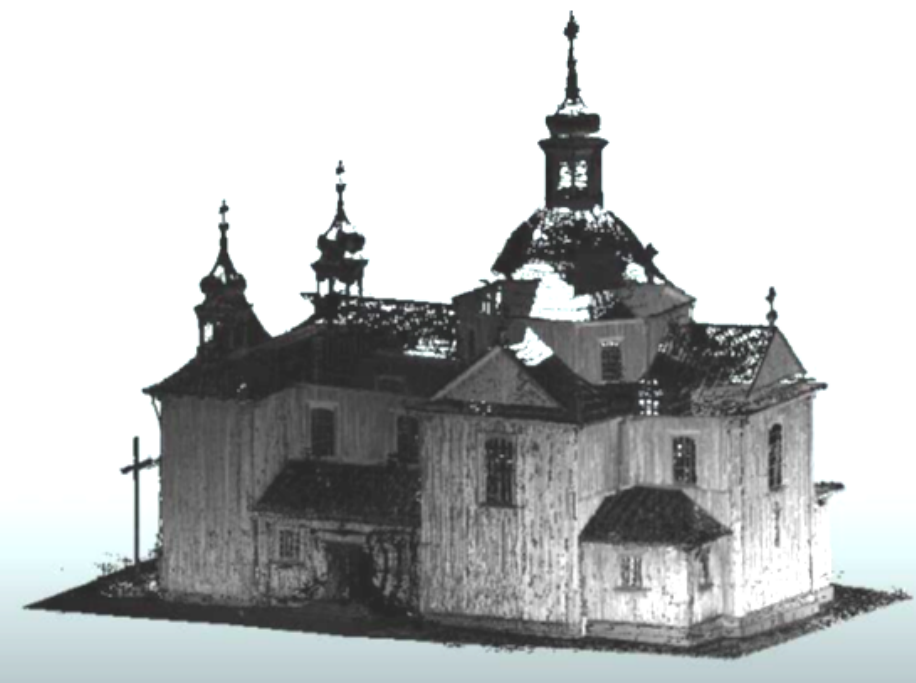

Figure 6

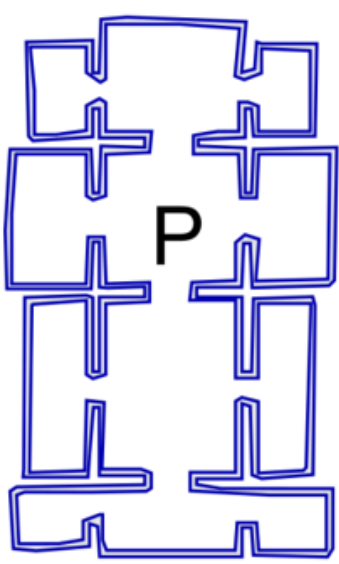

b)

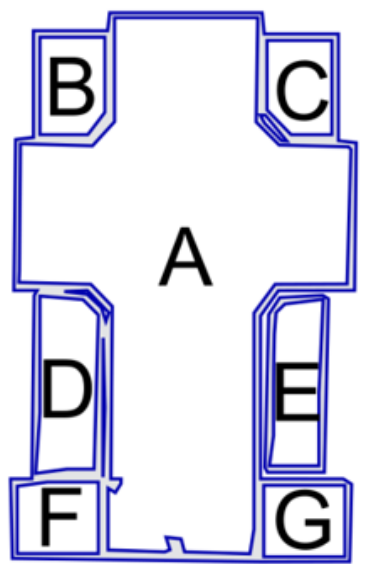

main floor and choir

Point cloud representing the church from the outside (a) and a floor plan based on horizontal crosssections through the point cloud (b).
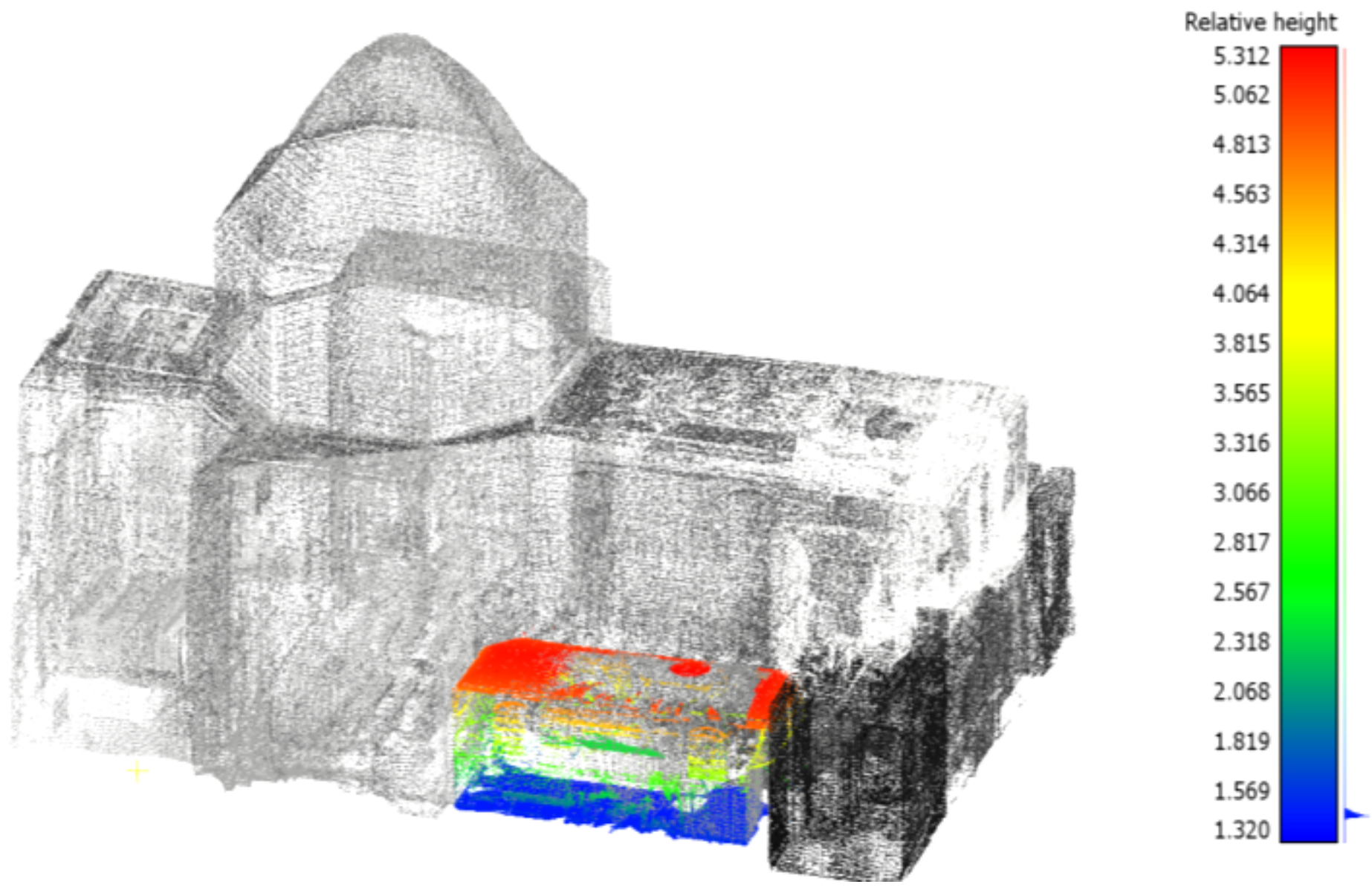

Figure 7 
Points used to measure the built-up area, volume and height of the room D (source: own study)
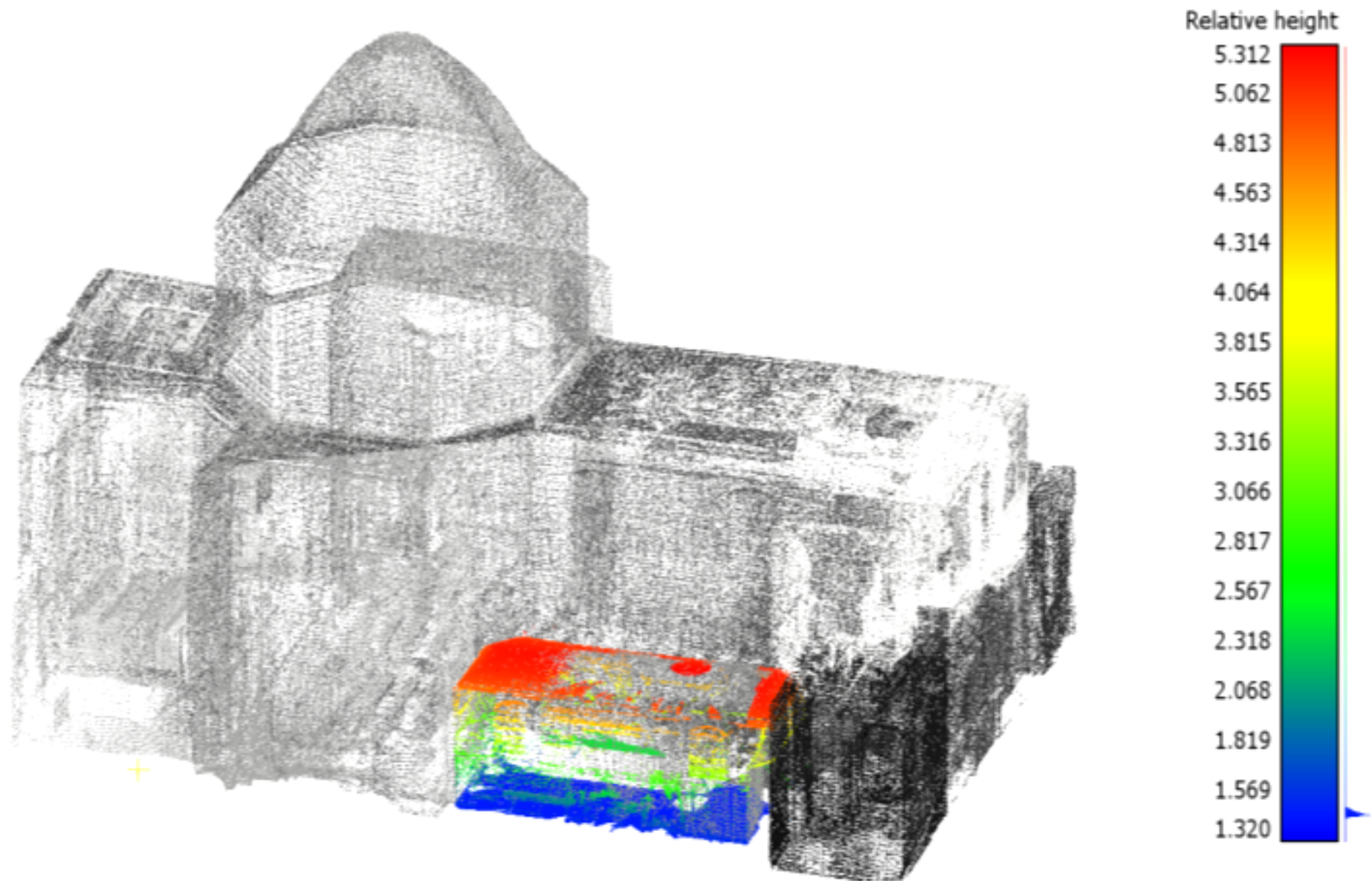

Figure 7

Points used to measure the built-up area, volume and height of the room D (source: own study) 


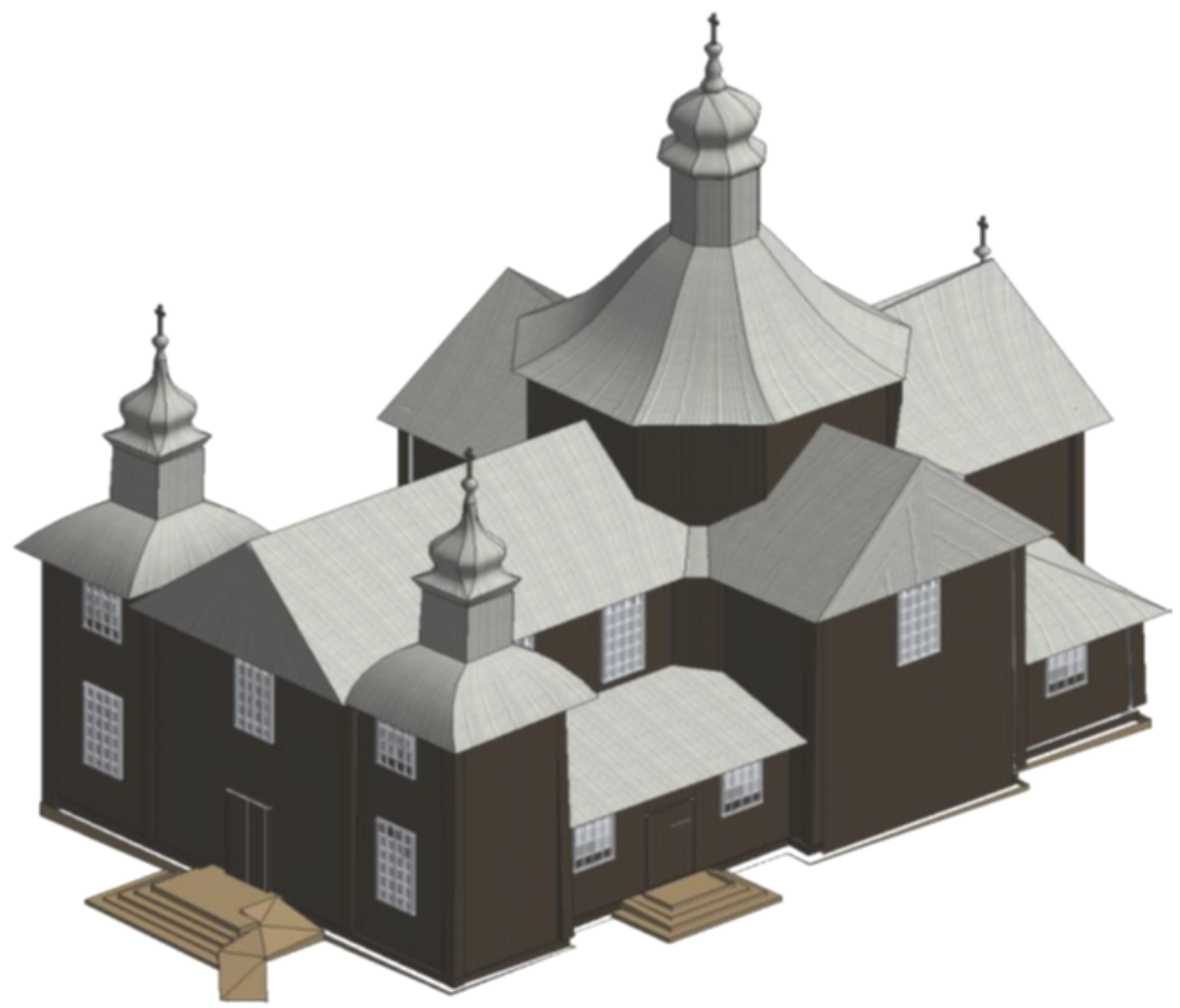

Figure 8

Model of the church St. Szczepan in Mnichów - southwest view 


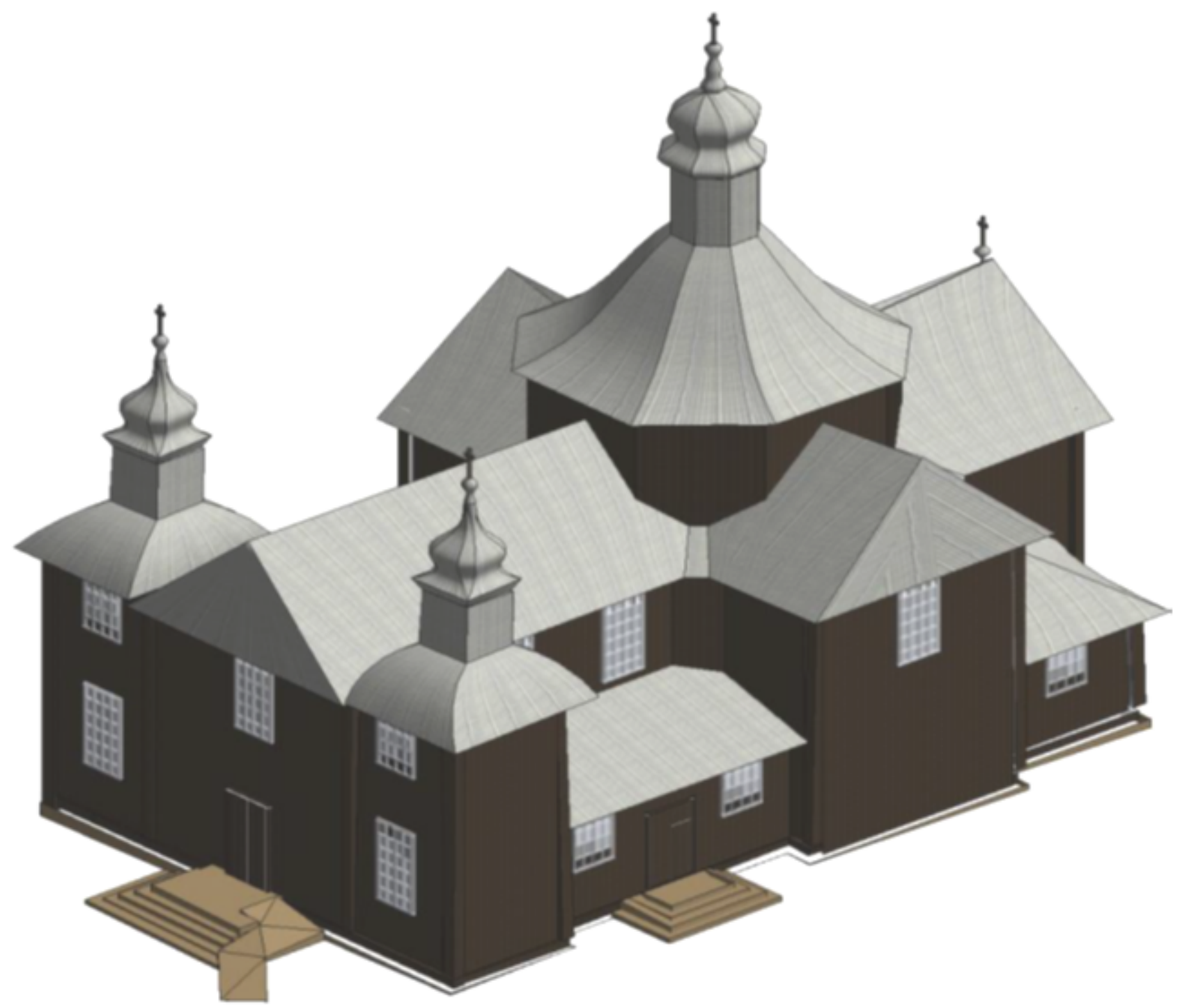

Figure 8

Model of the church St. Szczepan in Mnichów - southwest view 

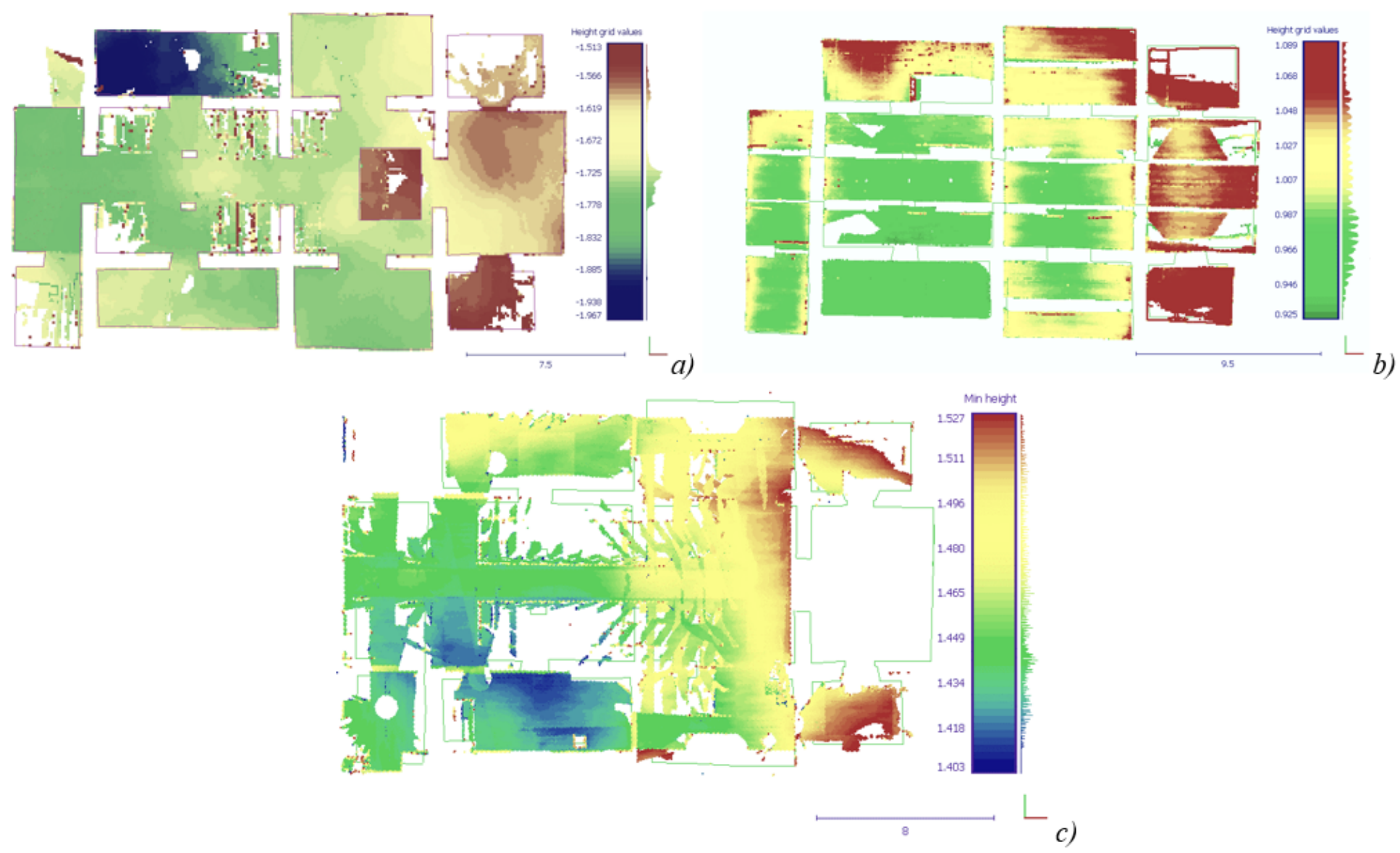

Figure 9

Verticality of the floor of the underground chapel (a) and its ceiling (b) and the floor of the nave (c) 

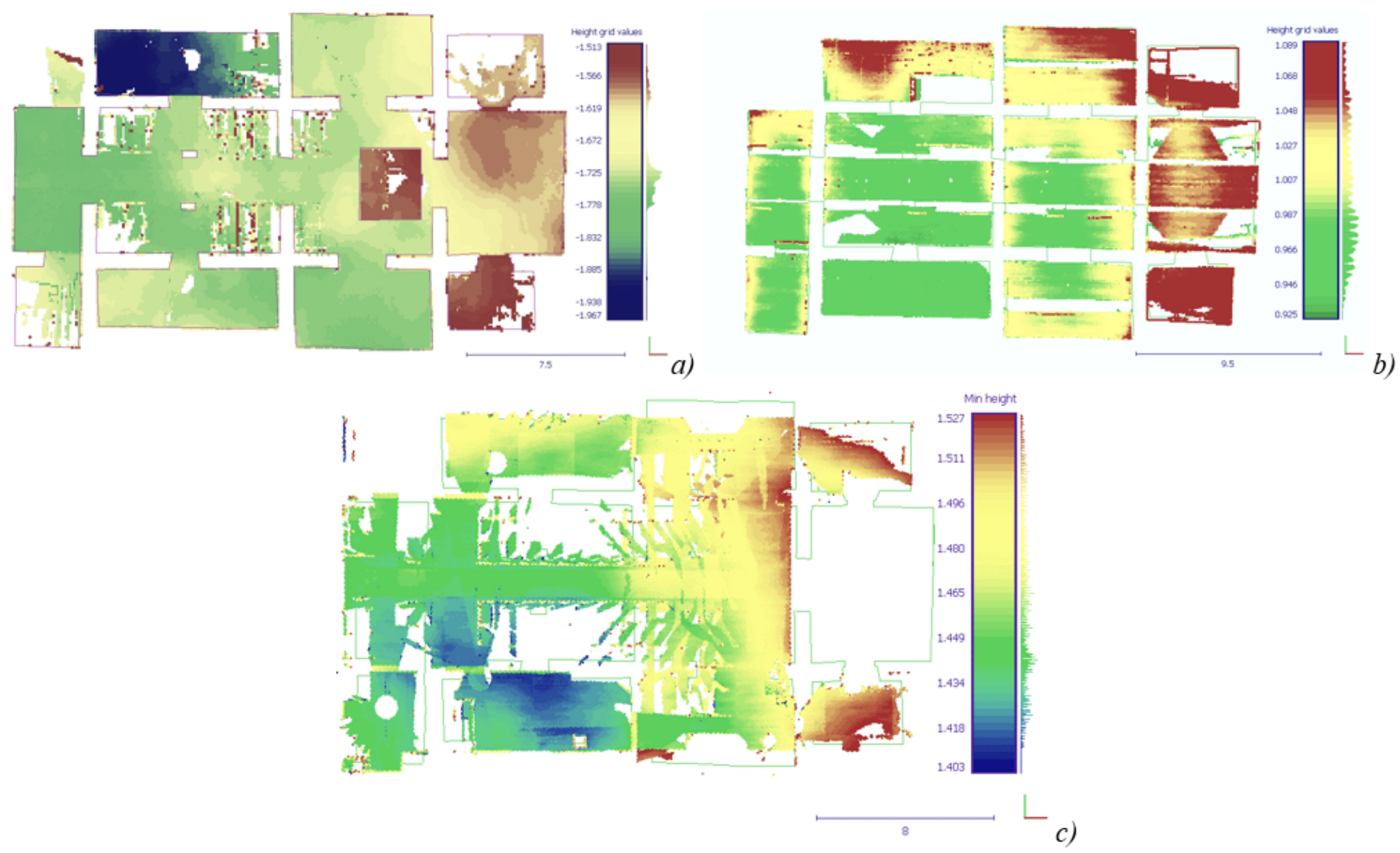

Figure 9

Verticality of the floor of the underground chapel (a) and its ceiling (b) and the floor of the nave (c) 
a)
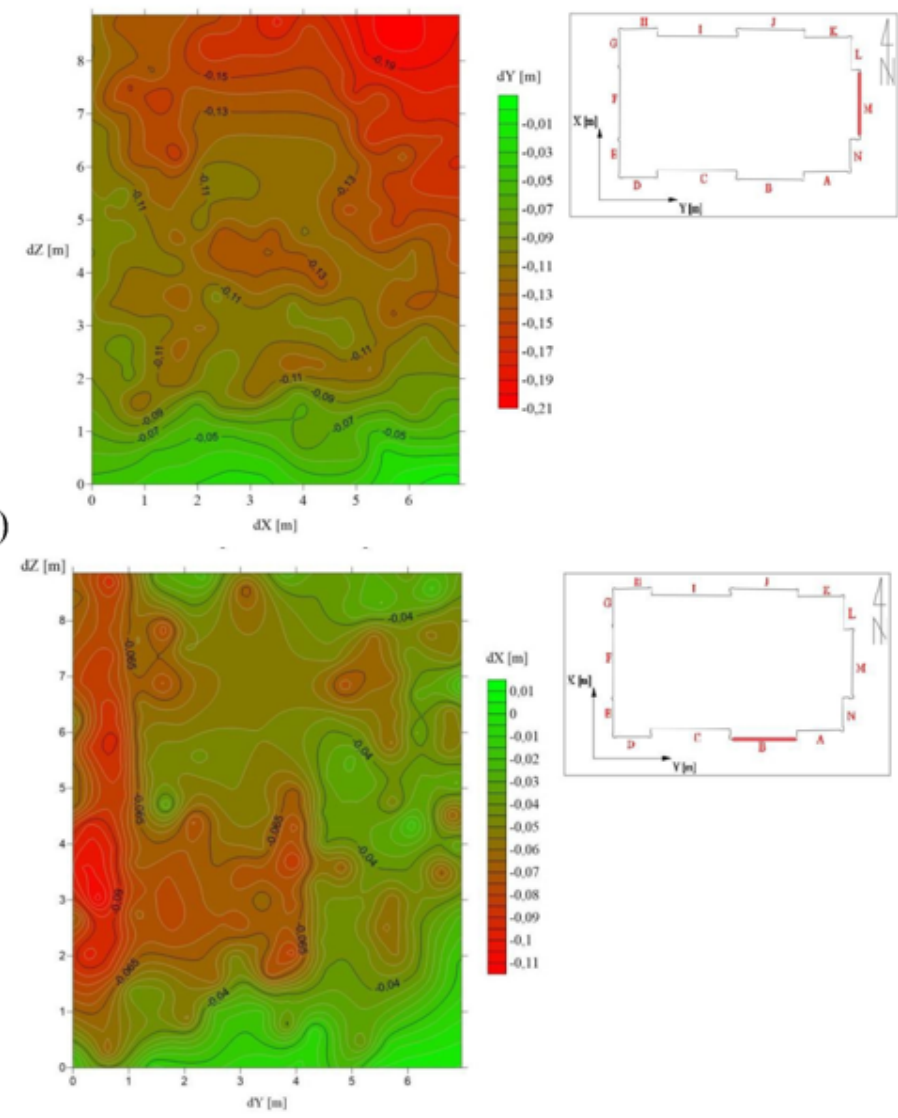

b)

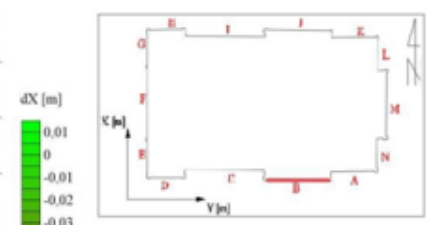

Figure 10

Deviations from the vertical wall of the external walls of the structure - a) walls " $M$ " and " $F$ " on the westeast axis, b) walls "B" and "J" on the north-south axis 
a)
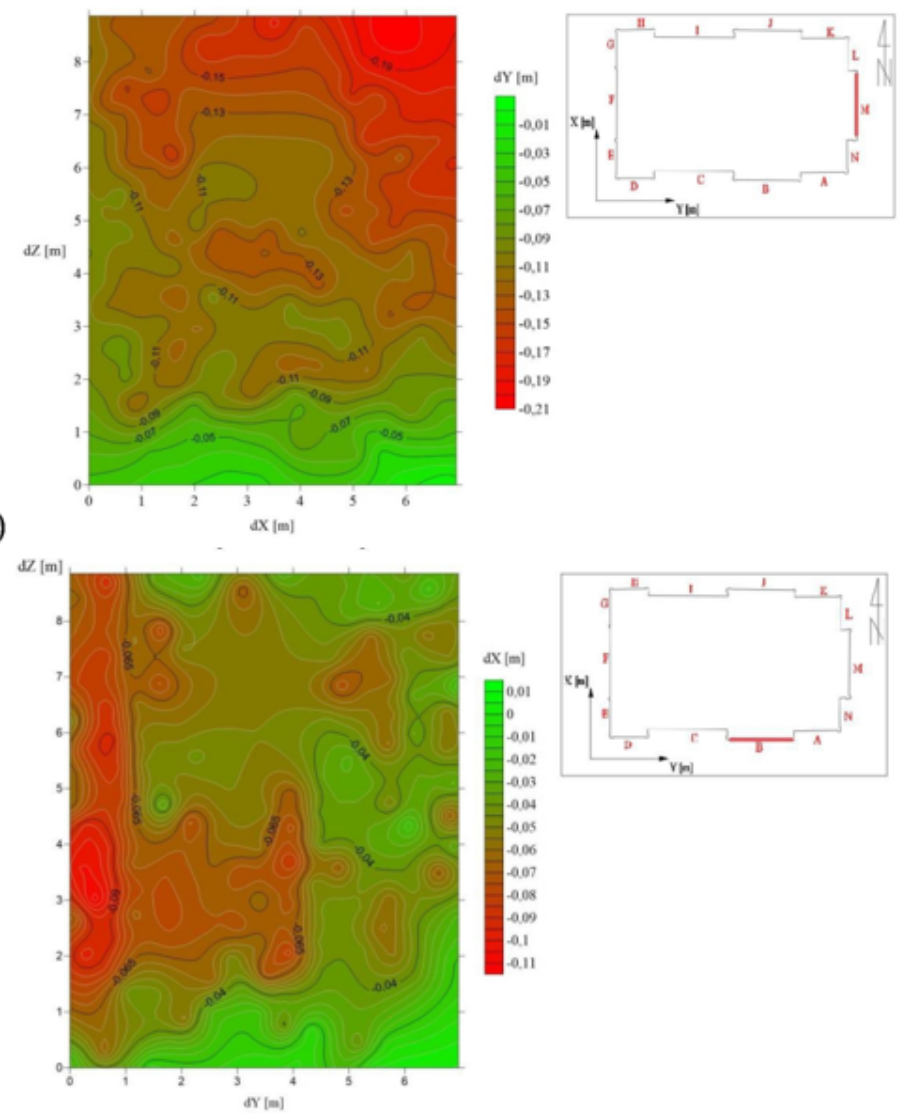

b)

\section{Figure 10}

Deviations from the vertical wall of the external walls of the structure - a) walls " $M$ " and " $F$ " on the westeast axis, b) walls "B" and "J" on the north-south axis 


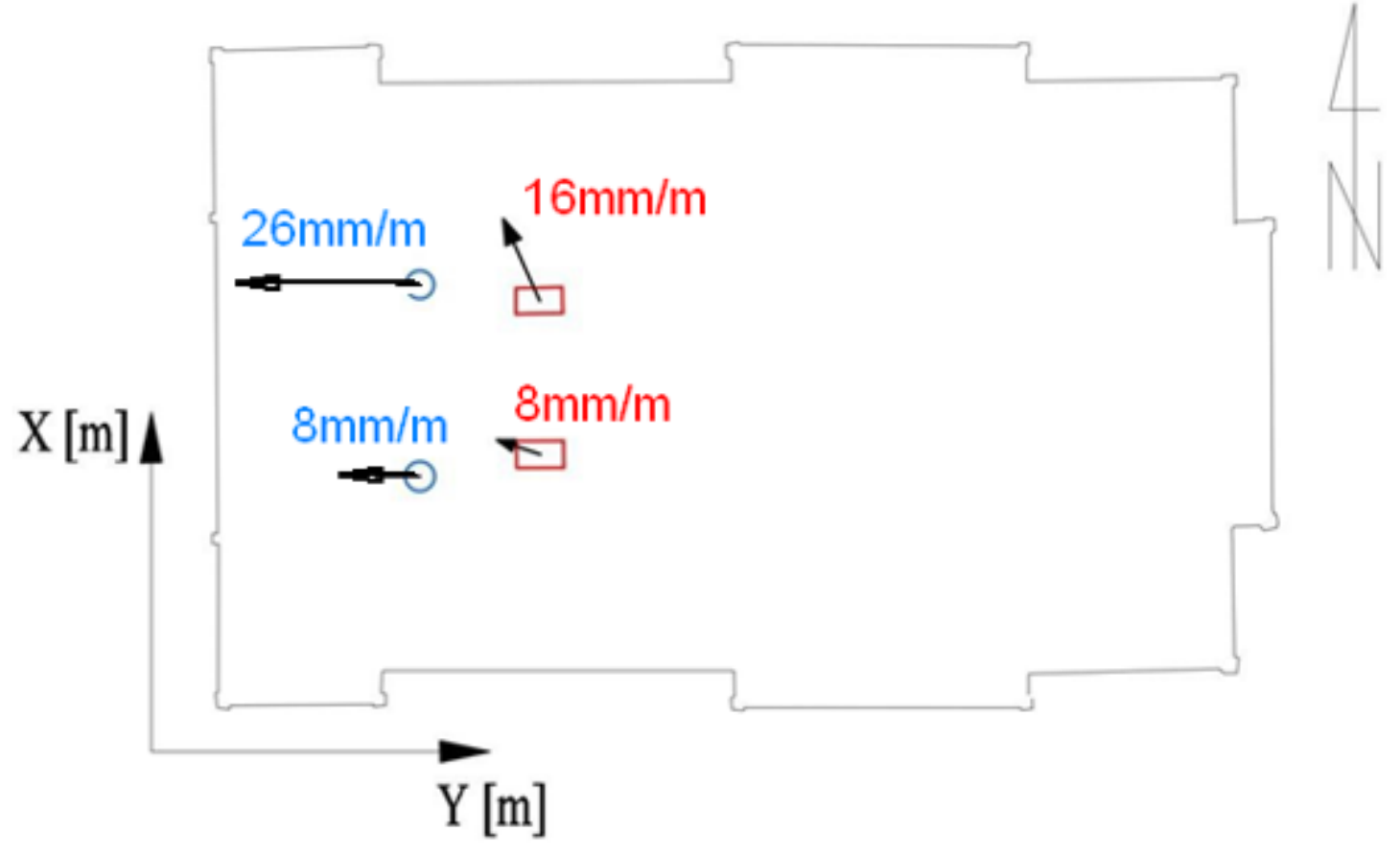

0 columns in the nave

$\square$ columns in the basement

Figure 11

Determined vectors of inclination of the column axes from the vertical. 


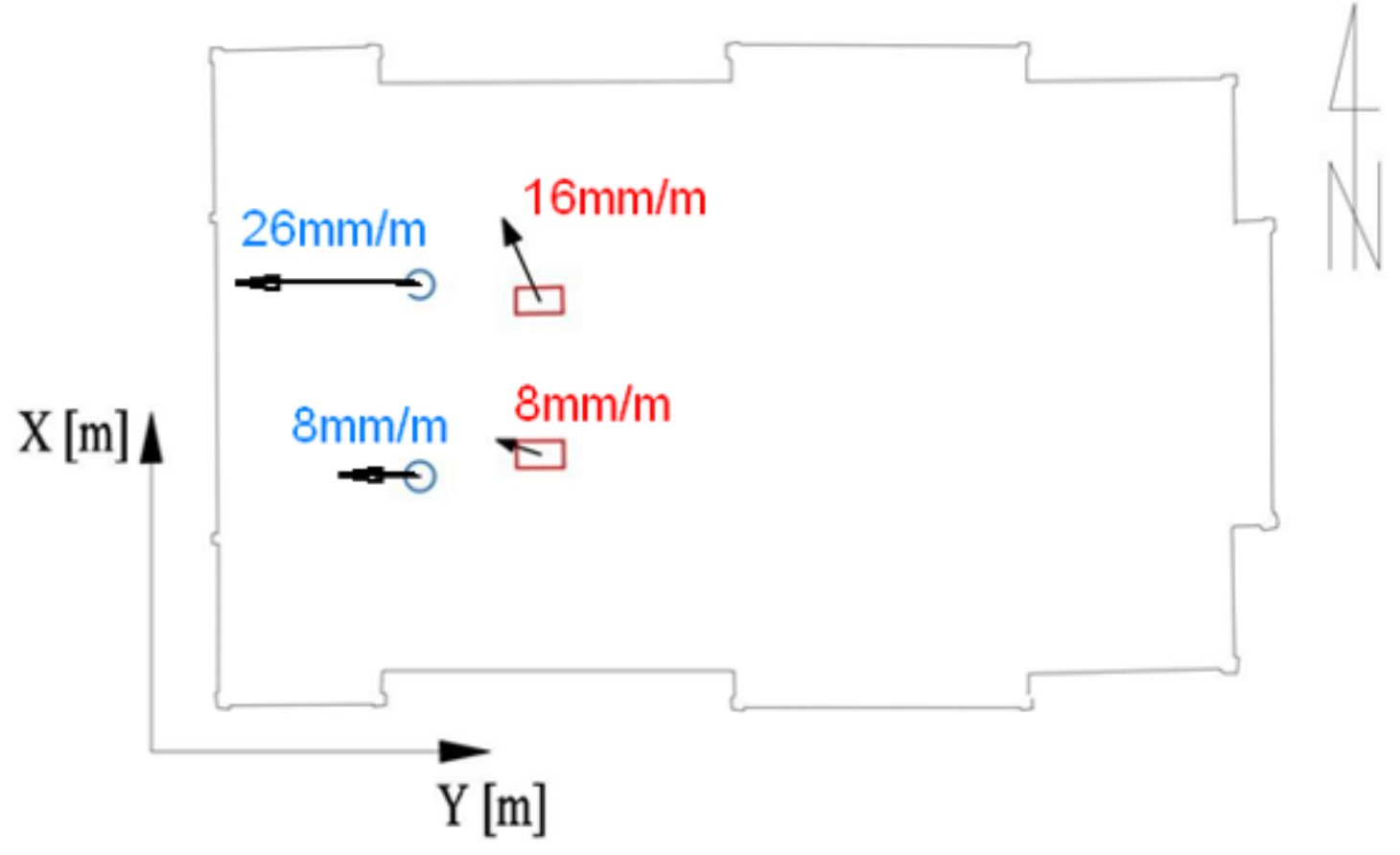

0 columns in the nave

$\square$ columns in the basement

Figure 11

Determined vectors of inclination of the column axes from the vertical. 

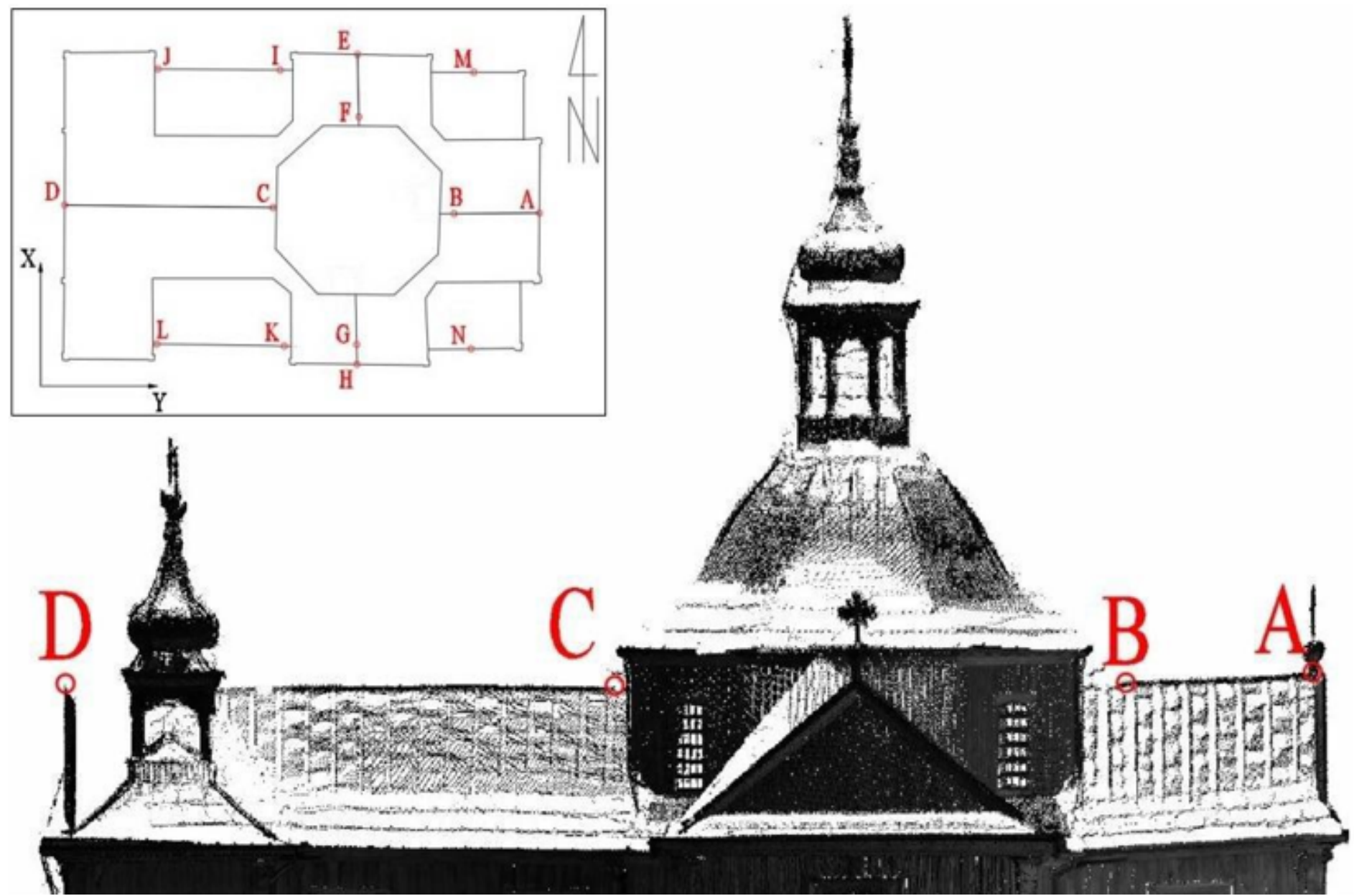

Figure 12

View of the ridge of the church roof west-east. 

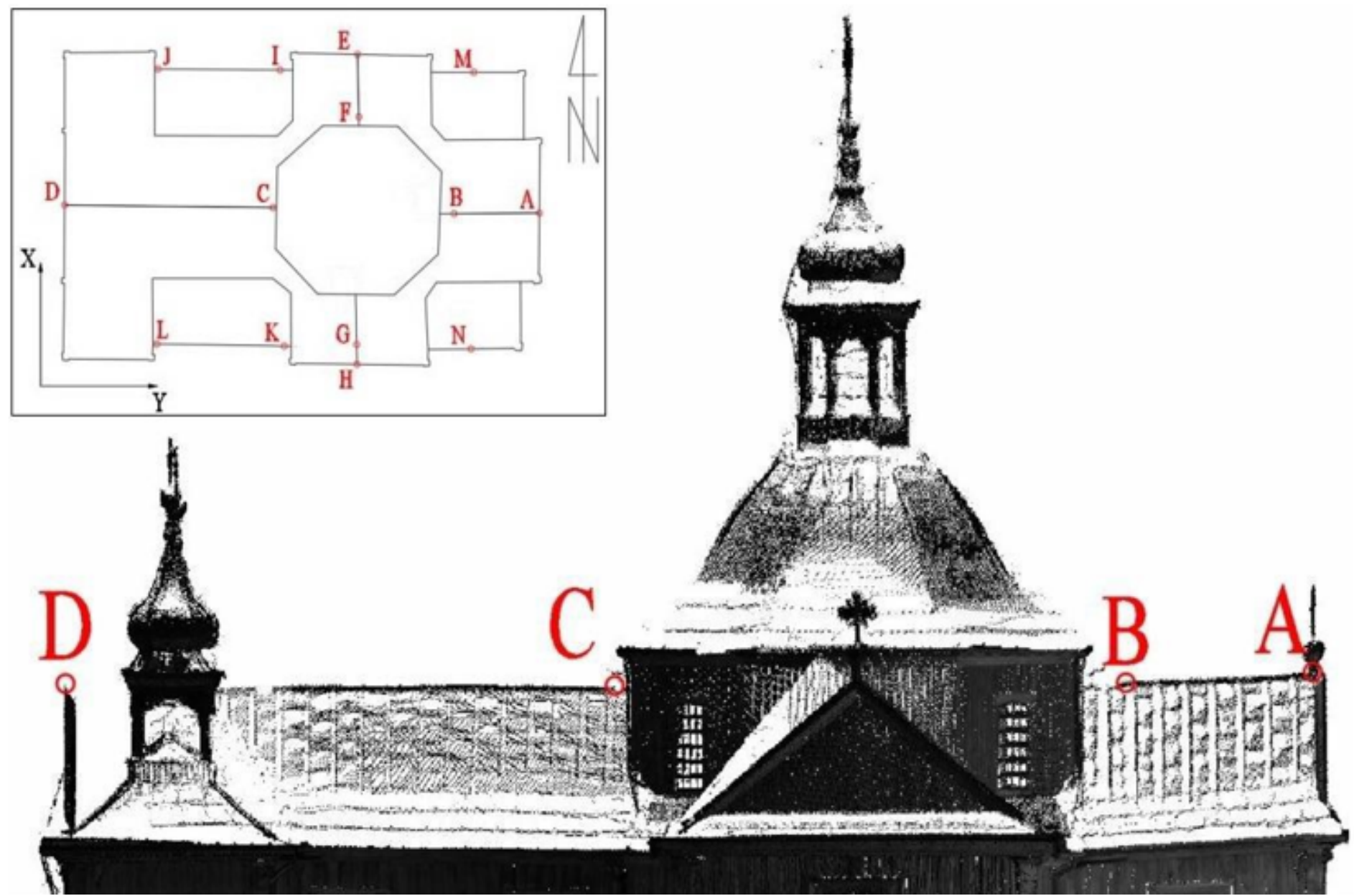

Figure 12

View of the ridge of the church roof west-east. 